\title{
İsrail Tarih Ders Kitaplarının Merceğinden Osmanlı İmparatorluğu*
}

\author{
Selim Tezcan** \\ Alper Sarıbaş***
}

The Ottoman Empire as Seen through the Lens of Israeli Textbooks for History

Abstract This study examines the treatment of Ottoman history in the Israeli Hebrew textbooks for history used from 1948 to 2014 . Relating the foundation period, all the books rely on the ghaza thesis. The Ottoman Empire of the classical age is appreciated for its centralist administration, efficient army, and tolerance toward non-Muslims. However, all the books accept the decline paradigm, and, because of the increased focus of the books of the 1990s and after on the "period of decline," the Ottoman image they project is a more negative one. The books relate a story of deterioration in all respects following the sixteenth century. The Ottoman government is criticized for its violent suppression of the Balkan revolts. Most Tanzimat-era reforms are considered to have been ineffectual. The Abdulhamid government is criticized for its oppressive rule, and the Young Turks for their ethnocentric policies. The wars in Gallipoli and Palestine are generally told from a British perspective. The older books' narrative of the developments concerning the Armenians is closer to Turkey's official theses than that of the more recent books.

Keywords: Israel, Ottoman Empire, history textbooks, ghaza thesis, decline paradigm.

\section{Giriş}

İki Dünya Savaşının sonrasında toplumların diğer ülkelere ve başka etnik-dinî gruplara ilişkin algılarının şekillenmesinde ders kitaplarının ne kadar önemli bir

* Bu makaleye temel oluşturan araştırma, Selim Tezcan'ın yürütücülüğünde gerçekleştirilen 214K010 numaralı, "İsrail ve Türkiye'deki İlk ve Ortaöğretim Seviyesi Tarih Kitaplarında Sırasıyla Türkler ve Yahudiler ile İlgili Konuların İşlenişi, 1948-2014” adlı TÜBİTAK projesi çerçevesinde gerçekleştirilmiştir. TÜBİTAK'a desteği için teşekkür ederiz.

** Ankara Sosyal Bilimler Üniversitesi.

***Ankara Üniversitesi. 
rol oynadığı gün yüzüne çıkmış; gerek devletler, gerekse farklı toplumsal kesimler arasındaki çatışmaların temelinde yatan husumet ortamının şekillenmesine hatırı sayılır bir katkıda bulundukları fark edilmiştir. Bu nedenle 1945 'ten itibaren ders kitabı incelemeleri UNESCO, Avrupa Konseyi ve Georg Eckert Enstitüsü gibi uluslararası kurumların yakın ilgisine konu olmuş, bu konuda konferanslar düzenlenmiş ve ders kitabı yazım ve tetkikine yardımcı olacak kılavuzlar hazırlanmıştır. ${ }^{1}$ Aynı zamanda Alman-Fransız, Alman-Polonya ve Alman-İsrail ortak ders kitabı komisyonları kurularak ders kitaplarındaki karşılıklı düşmanlık yaratıcı unsurlar ayıklanmıştır. Bu şekilde gelecekteki savaş ve çatışmaların önüne geçilmesine daha uygun bir toplumsal iklimin oluşturulacağı umut edilmektedir. Ayrıca dünyanın pek çok ülkesindeki araştırmacılar tarafından da ders kitapları çeşitli açılardan incelemeye tabi tutulmaktadır. ${ }^{2}$

Son zamanlarda Türkiye'de de ders kitaplarına dair önemli araştırmalar yürütülmüş, bu çerçevede tarih dersi için başka ülkelerde kullanılan ders kitaplarının Türkiye tarihini nasıl ele aldığını inceleyen çok sayıda akademik yayın yapılmıştır. ${ }^{3}$

1 Robert Stradling, Teaching 20th Century European History (Strasbourg: Council of Europe, 2001); Falk Pingel, The European Home: Representations of 20 $0^{\text {th }}$ Century Europe in History Textbooks (Strasbourg: Council of Europe, 2000); ayn yazar, UNESCO Guidebook on Textbook Research and Textbook Revision, ${ }^{\text {nd }}$ Edition (Paris and Braunschweig: UNESCO and Georg Eckert Institute, 2010).

2 Elie Podeh, The Arab-Israeli Conflict in Israeli History Textbooks, 1948-2000 (Westport, CT: Bergin \& Garvey, 2002), s. 1-7.

3 Türkiye'de yabancı ülkelerin ders kitaplarında Türk imajıyla ilgili olarak şimdiye kadar yapılmış en geniş kapsamlı proje için bkz. "Balkan ve Karadeniz Ülkelerinde Güncel Tarih Ders Kitaplarında Osmanlı/Türk İmajı,” TÜBİTAK 1001 Projesi, Proje No. 110K571, Proje Yürütücüsü Mehmet Hacısalihoğlu (İstanbul, 2014). Proje çerçevesinde Bosna-Hersek, Surbistan, Karadağ, Hirvatistan, Kosova, Makedonya, Arnavutluk, Bulgaristan, Yunanistan, Kıbrıs Rum Kesimi, Ermenistan, Azerbaycan, Rusya ve Gürcistan olmak üzere toplam 14 ülkenin ders kitapları incelenmiştir. Projeye katkıda bulunan araştırmacılar tarafından bugüne kadar konu hakkında yapılmış bilimsel yayınlardan bazıları için bkz. Neriman Ersoy Hacısalihoğlu, "Bulgaristan Tarih Algısında ve Tarih Ders Kitaplarında Devşirme Sistemi ve Yeniçeriler," Tarih Dergisi, 66 (2017), s. 129-154; Bülent Bilmez, "Arnavutluk Tarih Ders Kitaplarında Osmanlı/Türk İmgesi,” Osmanlı Araştırmaları, 49 (2017), s. 34380; Evren Balta ve Süheyla Demir, "Tarih, Kimlik ve Dış Politika: Rusya Federasyonu Güncel Tarih Ders Kitaplarında Osmanlı-Türk İmajı,” Bilig, 76 (2016), s. 1-31; Yıldız Deveci Bozkuş, Ermeni Ders Kitaplarında Türkler, (Ankara: TEPAV, 2016); aynı yazar, "Ermeni Tarih Ders Kitaplarında 1915 Olayları," TESAM Akademi Dergisi, 2 (2015), s. 89-105; aynı yazar, "Ermeni Tarih Ders Kitaplarında Türk İmgesi," Yeni Türkiye, 60 (2014), s. 1-45; Ozan Erözden, "Hırvatistan Tarih Ders Kitaplarında Osmanlı-Türk İmajı”" İ.Ü. Siyasal 
İsrail kitaplarında Selçuklu ve Türkiye Cumhuriyeti tarihi ile Osmanlı-Yahudi ilişkilerinin nasıl işlendiğini ele alan üç çalışma mevcuttur. ${ }^{4}$ Ancak doğrudan Osmanlı tarihinin nasıl işlendiği konusunda bir çalışma yoktur. İsrail'de de Arap imajı ve İsrail-Arap çatışmalarının İsrail ders kitaplarında nasıl yansıtıldığını ele alan pek çok araştırma olmasına rağmen ${ }^{5}$ bu kitaplarda Türk tarihinin nasıl yansıtıldığına

Bilgiler Fakültesi Dergisi, 50 (2014), s. 39-54; Jahja Muhasilović, "Image of the Ottomans in Bosnian Textbooks Published After 2007," Epiphany - Journal of Transdisciplinary Studies, 7/2 (2014), s. 82-91. Yabancı ülkelerin ders kitaplarında Türk imajı konusunda yapılmış diğer önemli yayınlardan bazıları için bkz. İsa Tak ve Nurses Yıldız, "1980-1990 Yılları Arasında Bulgaristan'da İlköğretim ve Ortaöğretim Kurumlarında Okutulan Tarih Ders Kitaplarında Türk ve Osmanlı Algısı,” Uluslararası Türk Eğitim Bilimleri Dergisi, 2 (2014), s. 67-100; Mümin İsov, "Bulgaristan Tarih Ders Kitaplarında Türk Azınlığın Yerine İlişskin Bazı Gözlemler,” Balkan Araştırma Enstitüsü Dergisi, 3 (2014), s. 37-51; Ahmet Şimşek ve Nigar Maharramova Cengiz, "Rusya Tarih Ders Kitaplarında Türk-Osmanlı İmgesi,” Türk Tarih Ĕ̈itimi Dergisi, 4 (2015), s. 225-58; Suat Kınıklığlu, "Images and Representations of Turks and Turkey in Soviet History Textbooks," International Textbook Research, 29 (2007), s. 259-71; Mehmet Ali Kapar, "Sovyetler Birliği Dönemi Ders Kitaplarında Eskiçağ Tarihi ve Eski Türk Tarihi'nin Öğretimi,” USAD, 5 (2016), s. 239-52; Ahmet Alibațić, "Images of the Ottomans in History Textbooks in Bosnia and Herzegovina," İlâm Araştırmalar Dergisi, 17 (2007), s. 103-37; Selçuk Ural, "Makedonyada 6, 7 ve 8. Sınıf Türkçe Tarih Ders Kitaplarında Osmanlı-Türk Algısı,” Tarih Okulu Dergisi, 7 (2014), s. 797-826; Gabriel Pirický, "The Ottoman Age in Southern Central Europe as Represented in Secondary School History Textbooks in the Czech Republic, Hungary, Poland and Slovakia," Journal of Educational Media, Memory, and Society, 5 (2013), s. 108-29; Mehmet Alpargu, "Türkiye ve Azerbaycan Tarih Ders Kitapları Üzerine Bazı Gözlemler," Atatürk Dergisi, 5 (2007), s. 1-13; Hülya Çelik ve M. Bilal Çelik, "Devrim Sonrası İran Ortaokul Tarih Ders Kitaplarında Türklere İlişkin Söylemlerin Analizi,” Türk Tarih Eğitimi Dergisi, 4 (2015), s. 202-24; Celâl Erdönmez, "Kıbrıs Tarihi Ders Kitaplarında Osmanlı Devrinde Kıbrıs’a Yapılan Sürgünlerle İlgili Bazı Tespitler," SDÜ Fen Edebiyat Fakültesi Sosyal Bilimler Dergisi, 15 (2007), s. 65-90.

4 Selim Tezcan, Mehmet Sadık Gür ve Alper Sarıbaş, "İsrail Tarih Ders Kitaplarının (19482014) Gözünden Selçuklular: Filistin-Kudüs Hâkimiyetleri ve Haçlı Seferleri ile Cihad Hareketinin Başlangıcındaki Rolleri,” Filistin Araştırmaları Dergisi, 2 (2017), s. 103-33; Selim Tezcan, Alper Sarıbaş ve Mehmet Sadık Gür, "İsrail Tarih Ders Kitaplarının (19482014) Gözünden Tanzimat’a Kadar Osmanlı-Yahudi İlişkileri,” TYB Akademi, 7, 21 (2017), s. 77-103; Selim Tezcan, Mehmet Sadık Gür ve Alper Sarıbaş, "İsrail Tarih Ders Kitaplarında Türk İstiklal Savaşı ve Cumhuriyet Dönemi,” Bilig, 86 (2018), s. 137-67.

5 Yoram Bar-Gal, "The Image of the 'Palestinian' in Geography Textbooks in Israel," Journal of Geography, 93 (1994), s. 224-32; Daniel Bar-Tal, "The Arab Image in Hebrew School Textbooks," Palestine-Israel Journal, 8 (2001), s. 5-18; Elie Podeh, "History and Memory in the Israeli Educational System: The Portrayal of the Arab-Israeli Conflict in History Textbooks (1948-2000)," History \& Memory, 12 (2000), s. 65-100; ayn yazar, "Univocality within Multivocality: The Israeli-Arab-Palestinian Conflict as Reflected in Israeli History 
odaklanan müstakil bir inceleme bulunmamaktadır. Oysa özellikle Osmanlı tarihi hem İmparatorluğun yüzyıllarca Sefarad Yahudilerine ev sahipliği yapmış olması bakımından, hem de Filistin’in 16. yüzyılda İmparatorluğa dâhil olması ve İsrail devletinin bu Osmanlı bakiyesi topraklarda kurulması açısından İsrail için önem taşımaktadır. Diğer yandan II. Dünya Savaşı'nın akabinde İsrail'in kuruluşu ve Müslüman ülkeler arasında ilk olarak Türkiye tarafından tanınması, 1990'larda iki ülkenin yakın bir stratejik işbirliğine gitmesi, 2000’lerde siyasi gerginliklere rağmen ekonomik ilişkilerin gelişerek devam etmesi ve son dönemdeki elçi değiş tokuşu ile siyasi planda da tekrar bir yakınlaşmanın gerçekleşmesi açısından da Osmanlı tarihinin İsrail ders kitaplarında nasıl işlendiği konusu önem taşımaktadır. Konunun incelenmesiyle, İsrail ve Türkiye'de karşı taraf hakkında mevcut olan resmi ve toplumsal algıların kavranmasına da bir katkı sağlanmış olacaktır.

İsrailli araştırmacılar tarafından yapılan iki çalışmada, Osmanlı tarihinin İsrail tarih ders kitaplarında nasıl işlendiğine kısaca değinilmektedir. Eyal Naveh, "La imagen de Europa y del mundo árabe-islámico en el currīculo escolar y los libros de texto de historia en Israel" [İsrail'deki Okul Müfredatı ve Tarih Ders Kitaplarında Avrupa ve Arap-İslam Dünyası İmgesi] başlıklı çalışmasının iki sayfasında konuyu ele almaktadır. ${ }^{6}$ Sadece 1990 'ların sonlarında yayımlanmış iki ders kitabını inceleyen ve Osmanlı'nın son yüzyılı ile Tanzimat'ı konu edinen pasajlara odaklan Naveh, Osmanlı İmparatorluğu'nun kitaplarda o zamanlar tüm İslâm âleminin içine düşmüş olduğu zafiyetin bir timsali olarak sunulduğunu, içeride başına buyruk valiler ile milliyetçi akımların başını çektiği merkezkaç kuvvetlere ve dışarıda da Avrupa’nın baskısına dayanamadığı için bütünlüğünü koruyamadığından söz edildiğini belirtir. Zamanında gayrı-Müslim cemaatlerin kendi kültür ve kurumlarını geliştirmelerine müsaade edilmiş olsa bile Tanzimat sürecinde getirilen yeniliklerin ve gayrı-Müslimlere tanınan eşitliğin muhafazakâr Müslümanların direnişi yüzünden hayata geçirilemediği, Hristiyanların kıyımlara uğradığı, 1876 Anayasası da II.

Textbooks, 2000-2010," Journal of Educational Media, Memory, and Society, 2 (2010), s. 4662; aynı yazar, Arab-Israeli Conflict; Ismael Abu-Saad, "The Portrayal of Arabs in Textbooks in the Jewish School System in Israel," Arab Studies Quarterly, 29 (2007), s. 21-38; Nurit Peled-Elhanan, Palestine in Israeli School Books: Ideology and Propaganda in Education (London: I.B. Tauris, 2012); Rafi Nets-Zehngut, "Israeli Approved Textbooks and the 1948 Palestinian Exodus," Israel Studies, 18/3 (2013), s. 41-68.

6 Eyal Naveh, "La imagen de Europa y del mundo árabe-islámico en el currīiculo escolar y los libros de texto de historia en Israel" [İsrail'deki Okul Müfredatı ve Tarih Ders Kitaplarında Avrupa ve Arap-İslam Dünyası İmgesi], Luigi Cajani (ed.), Conociendo al otro: El islam y Europa en sus manuales de historia, (Madrid: Fundación ATMAN, 2008), s. 196-97. 
Abdülhamid tarafından rafa kaldırılınca İmparatorluğun çöküşüne kadar modern ve seküler olamadığı savlarının kitaplarda yer aldığını kaydeder. Ancak Naveh’nin bu tespitleri yaparken sadece kendi döneminde yayınlanmış iki kitaba dayanması, vardığı sonuçların genelleştirilmesini zorlaştırmaktadır.

Elie Podeh ise konuyu The Arab-Israeli Conflict in Israeli History Textbooks, 1948-2000 adl kitabındaki "The Ottoman Empire and the Image of the Turks" başlıklı dört sayfalık kısımda ele almıştır. Y Yazar 1990'lara dek basılan ders kitaplarında gayet olumsuz bir Osmanlı imgesinin sunulduğunu, Osmanlı Devleti'ni Sultanın despotça idare ettiği, yerel yöneticilerin giderek merkezden koptuğu, rüşvet, sömürü ve çatışmaların hüküm sürdüğü bir yer olarak resmedildiğini savunur. İmparatorluğun gayrı-Müslimlere gösterilen hoşgörülü muamele gibi olumlu yönlerinden bahsedilmediğini ileri sürer. 1990’lardan itibaren basılan kitaplarda daha müspet bir imge sunulsa da hâlâ bazı olumsuz klişelere rastlandığını not eder. Ancak konuya kısıtlı bir yer ayırdığı incelemesinde, detaylara inmez; özellikle de bu tespitlerin Osmanlı tarihinin tüm dönemleri için geçerli olup olmadığı gibi önemli bir soruyu irdelemez. Mevcut çalışma ise konuya odaklanan müstakil bir inceleme olarak 1948'den günümüze kadar konuya değinen tüm tarih ders kitaplarını analiz etme ve Osmanlı tarihinin her bir dönemi hakkındaki anlatı ve yaklaşımlarını detaylı olarak değerlendirme amacını taşımaktadır.

İsrail'de ders kitapları 1950'ler ve 60'ların ilk yarısı boyunca bir yandan öğretmen ve akademisyenler, diğer yandan da İsrail Eğitim Bakanlığı’nın, ders kitaplarıyla doğrudan ilgili olmayan şubelerinde çalışan uzman memurlar tarafından yazılıyordu. 1966'da Bakanlık bünyesinde Müfredat Şubesinin kurulmasıyla birlikte 1990'ların başına kadar kitaplar bu şubedeki uzmanlar tarafından yazılmaya başlandı. Ancak bütçe kısıntıları ve devletin bizzat ders kitabı yazmasına karşı artan itirazlar sonucunda, 1990'ların başında kitap yazımı tamamen özel sektördeki yayınevlerine ve bu yayınevleriyle çalışan akademisyen ve öğretmenlere bırakıldı. Ders kitaplarının bizzat Müfredat Şubesi uzmanları tarafından yazıldığı ve dolayısıyla doğrudan onaylanmış kitaplar listesine girdiği 1966-1990 dönemi dışında, kitaplar 1950’lerden beri Bakanlık bünyesinde faaliyet gösteren Onaylama Şubesinin denetim ve onay sürecine tabidir. Şube her kitap için Müfettişler Şubesinin önerdiği uzmanlar arasından biri öğretmen diğeri de akademisyen olmak üzere ikişer hakem seçerek denetim komisyonları kurmakta, bu komisyonlar tarafindan uygun bulunan kitaplar da onaylı kitaplar listesine alınmaktadır. Buna karşılık okullarda onaysız

7 Podeh, Arab-Israeli Conflict, s. 77-80. 
kitapların da kullanıldığına rastlanmaktadır; özellikle 1990’larda onaysız kitap kullanımının \%75 gibi yüksek oranlara ulaşmasından sonra Bakanlık kullanılan kitaplar üzerindeki kontrolünü tekrar sıkılaştırmıştır. ${ }^{8}$

1970’lerin ilk yarısına kadar yayınlanan ders kitapları ağdalı, kimi zaman öznel bir dile kaleme alınır, bir iki harita dışında hemen hiçbir resim veya şekil barındırmazken 1970’lerin ikinci yarısından itibaren bu durum değişmeye başlamıştır. Giderek zenginleşen bir görsel malzemeye yer verilen bu kitaplarda, daha nesnel bir üslup ve modern öğretim metodolojileri benimsenmiştir. Buna paralel olarak içerik bakımından da 1950 'ler ve 60'ların kitaplarında görülen etnosentrik ve milliyetçi yaklaşımda, 1970'lerin ikinci yarısından itibaren bir yumuşama gerçekleşmiştir. 1990'ların ikinci yarısından itibaren temeldeki Siyonist çerçeve değişmemekle birlikte daha çoğulcu perspektiflere de yer veren bir anlayış belirginleşmiştir. Günümüz itibariyle lise düzeyine kadarki ders kitaplarında tarihle ilgili konular Eskiçağdan Yeniçağa kadar kronolojik bir sırayla işlenmekte, lise düzeyinde ise Eskiçağ ve Ortaçağ hakkındaki birer ders dışında milliyetçiliğin ve Siyonizm'in gelişimi, Manda dönemi Filistini'ndeki Yahudi cemaatiyle İsrail'in tarihi ve Nazizm ile Soykırım gibi spesifik konuları işleyen ders kitapları okutulmaktadır. Ders kitaplarının sınıfta fiilen çok az kullanıldığı ve öğretmenlerin kendi seçtikleri ders malzemelerinden yararlanmakta serbest olduğu İngiltere, Hollanda ve İspanya gibi ülkelerden farklı olarak, İsrail'de Doğu Avrupa ve Orta Doğu ülkelerine benzer bir şekilde, ders kitapları sınıfta daha çok takip edilmektedir. Ancak Bakalorya sınavı yaklaştıkça öğretmen ve öğrencilerin yaygın biçimde rağbet ettiği, sınav hazırlığına yönelik kitap ve malzemeler, lisenin son dönemlerinde ders kitaplarının geri plana itilmesine yol açabilmektedir. ${ }^{9}$

Mevcut çalışma için 1948'den bu çalışmanın temelinde yatan projenin başlangıç tarihi olan 2014'e kadar İsrail'deki seküler ve dinî devlet okullarında okutulmak üzere hazırlanmış İbranice tarih ders kitapları tarandı. İncelenecek İsrail tarih ders kitapları belirlenir ve tedarik edilirken İsrail Milli Eğitim Bakanlığı'nın onaylanmış ders kitapları listesinden, George Eckert Enstitüsü’nden, İsrail Milli Kütüphanesi'nden ve İsrail'deki ticari kitabevlerinden yararlanıldı. 1948 ile 2014 arasında basılmış İbranice tarih ders kitaplarının 49'unda Selçuklu, Osmanlı veya Türkiye Cumhuriyeti tarihine yer verildiği tespit edildi. Bunlar arasından Osmanlı İmparatorluğu tarihi üzerinde duranlar ise 1958 ile 2014 arasında yayınlanmış

8 Nets-Zehngut, "Israeli Approved Textbooks," s. 47-49.

9 Elie Podeh, "History and Memory," s. 69-70; aynı yazar, Arab-Israeli Conflict, s. 13-14; Naveh, "La imagen de Europa," s. 189-90, 200-202. 
toplam 23 kitaptı. ${ }^{10}$ Kitapların biri ilkokul, sekizi ortaokul, on dördü de lise için hazırlanmıştı. İkisi 1950 'lerde, ikisi 60'larda, beşi 70’lerde, ikisi 80 'lerde, altısı 90’larda, altısı da 2000'lerde basılmıstı. Kitapların büyük kısmının 1970’lerde, 90 'larda ve 2000 'lerde yayınlanmış olması dikkat çekiciydi.

Çalışmanın veri toplama kısmında ders kitapları incelenerek ilgili pasajları önemlerine göre olduğu gibi veya özet olarak tercüme edildi. İçerik analizinde

10 İncelenen kitaplar tarih sırasıyla şunlardır: Michael Ziv ve Jacob Toury, Divrey ha-Yamim - ha-Zeman ha-Hadash [Kronikler - Yakınçağ], Cilt 2 (Tel Aviv: Yavneh, 1958); Michael Ziv, Haim Hillel Ben-Sason ve Jacob M. Landau, Divrey ha-Yamim [Kronikler], Cilt 2 (Haifa: Yuval, 1959); Michael Ziv, Samuel Ettinger ve Jacob M. Landau, Divrey haYamim [Kronikler], Cilt 4, Bölüm 1 (Haifa: Yuval, 1963); Jacob Toury ve Dan Helmut Schmidt, Toldot ha-Amim ba-Zeman ha-Hadash [Yakınçağda Halkların Tarihi], Cilt 3 (Tel Aviv: Yavneh, 1967); Victor Tcherikover, Historya Klalit [Genel Tarih], Cilt 5 (Tel Aviv: Ts'erikover, 1970); Shlomo Na'aman ve Aryeh Kasher, Toldot Yemey ha-Beynayim ba-Amim uve-Yisrael [İsrail ve (Diğer) Halklar Arasında Ortaçağ Tarihi] (Tel Aviv: Amihai 1972); Jacob Toury ve Dan Helmut Schmidt, Toldot ha-'Amim ba-Zeman ha-Hadash [Yakınçağda Halkların Tarihi], Cilt 2 (Tel Aviv: Yavneh, 1973); Michael Ziv ve Jacob Toury, Divrey ha-Yamim - ha-Zeman ha-Hadash [Kronikler - Yakınçağ], Cilt 1 (Tel Aviv: Yavneh, 1973); Jacob Katz ve Mosche Hershko. Yisrael veha-'Amim [İsrail ve (Diğer) Halklar], Bölüm 2 (Tel-Aviv: Tel Aviv Dvir, 1974); Menahem Kedem, Perekim be-Toldot Yisrael ba-Méot ha-18 veha-19 [18. ve 19. Yüzyıllarda İsrail (Halkı) Tarihinden Fasıllar] (Tel Aviv: Or-'am, 1986); Shelomoh Shavit (ed.), Toldot Yisrael veha-'Amim [İsrail ve (Diğer) Halkların Tarihi], Bölüm 2 (Kudüs: Maalot, 1987); Eyal Naveh, ha-Meah ha-20: Meah she-Hafka Sidrey 'Olam [20. Yüzyıl: Dünyanın Düzenini Değiştiren Yüzyıl] (Tel Aviv: Sifre, 1995); Ketsi'ah Tabibiyan (ed.), Masa'el ha-'Avar: Mi-Yemey ha-Beynayim ve-'ad ha-'Et ha-Hadasha [Geçmişe Yolculuk: Ortaçağdan Yakınçağa] (Ramat Aviv: Matach, 1997); Elie Barnavi, Ha-Meah ha-20: Toldot Am Yisrael ba-Dorot ha-Aharonim [20. Yüzyıl: İsrail Halkının Günümüzdeki Tarihi] (Tel Aviv: Sifre, 1998); Akiva Doron (ed.), Mi-Dor le-Dor [Nesilden Nesile], Bölüm 3 (Kudüs: Misrad ha-hinukh veha-tarbut, 1998); Israel Zingrov ve David Shahar, 'Am ve-'Olam [Halk ve Dünya], Cilt 1 (Rehovot: 'Idan, 1998); Eli'ezer Domkeh (ed.), Ha-'Olam veha-Yehudim ba-Dorot ha-Aharonim [Günümüzde Dünya ve Yahudiler], Bölüm 2, Cilt 1 (Kudüs: Zalman Shazar Center, 1999); Shulah Inbar, Mahapekhah u-Geulah be-Yisrael uv-'Amim [İsrail ve (Diğer) Halklar Arasında Devrim ve Özgürleşme], Bölüm 1 (Petach Tikva: Lilach, 2006); Moshe Bar-Hillel ve Shula Inbar, 'Olam Leumi [Milli Dünya], Bölüm 1 (Petach Tikva: Lilach, 2008); Eli'ezer Domkeh, Hanah Urbach ve Tsafrir Goldberg, Ha-Leumiyut: Reshit ha-Derekh [Milliyetçilik: Yolun Başı] (Kudüs: Zalman Shazar Center, 2008); Yigal Mish'ol, Ha-Leumiyut ha-Modernit ve-Reshit ha-Tsiyonut [Modern Milliyetçilik ve Siyonizmin Başlangıc1] (Me'ala Edomim: Hay Sikhol, 2011); Yuval Kovarsky, Ha-Leumiyut be-Yisrael uv-Amim: Reshit ha-Derekh 'ad 1920 [İsrail ve (Diğer) Halklar Arasında Milliyetçilik: Yolun başı, 1920’ye Kadar] (Kinneret: Motsiim le-Or, 2014); Iloni Orli, Shalhevet Ofir ve Zehavit Schenkolewski, Ve-Ele Toldot [İşte Tarih] (Ramat Aviv: Matach, 2014). 
kodlar tümevarım yöntemi ile belirlendi. Kitaplardan toplanan ham veriler araştırmacılar tarafından incelenerek kodlar saptandıktan sonra her araştırmacı payına düşen kodlar ile verileri etiketledi; etiketlenen veriler karşılaştırıldı. Son aşamada ise kronolojik ve bağlamsal ilişkiye sahip kodlar bir araya getirilerek temalar oluşturuldu. Temaların altı ana başlık altında toplanabileceği görüldü: 1) Osmanlı Devleti'nin Kuruluşu ve Fetihleri, 2) Kuruluştan Klasik Döneme Osmanlı Kurumları, 3) Gerileme Dönemi ve Bağımsızlık Hareketleri, 4) Tanzimat ve II. Abdülhamid Dönemi, 5) Jön Türkler, 1908 Devrimi ve Yönetimdeki Politikaları, 6) I. Dünya Savaşı Sırasında Osmanlı İmparatorluğu. Bu altı başlığa değinen kitapların yıllara göre dağılımına bakıldığında, Osmanlı’nın kuruluş ve klasik dönemleri üzerinde daha eski tarihli, özellikle 1970'lerde basılmış kitapların ağırlıkla durduğu, biri dışında 2000'lerde basılan hemen hiçbir kitabın bu dönemlere yer vermediği ortaya çıkmaktadır. 1990 'lar ve 2000'lerde yayınlanan kitaplar Osmanlı'nın dönemlerine çok daha fazla ağırlık vermekte, hele 2000'lerde basılanlar neredeyse tamamen "gerileme devri" olarak sundukları döneme yoğunlaşmaktadır.

Makalenin izleyen kısımlarında bu altı ana başlık altındaki muhtelif temaların kitaplarda nasıl ele alındığ 1 incelenecektir.

\section{Osmanlı Devleti'nin Kuruluşu ve Fetihleri}

Kitapların Osmanlı Beyliği’nin kuruluşu ve fetihlerle genişleyerek bir İmparatorluğa dönüşmesi üzerinde detaylı olarak durduğu göze çarpmaktadır. Bu konular nötr, hatta olumlu bir yaklaşımla ele alınırken ikinci kısımda göreceğimiz gibi fetihlerin sonuçları daha olumsuz bir perspektiften değerlendirilmektedir.

\subsection{Kuruluş ve Fetibler}

Osmanlı Devleti'nin kuruluşu hakkında bilgi veren kitapların anlatılarına tipik bir örnek olarak 1974 basımı Yisrael veha-Amim'de yer alan pasaj gösterilebilir. Pasajda Osmanlıların Avrupa'daki fetihleri detaylarıyla anlatılmaktadır. Daha İstanbul'un fethinden önce Türklerin Çanakkale'ye yönelerek Balkan Yarımadasını ele geçirdikleri, buradaki Hıristiyan halklarla ağır savaşlara tutuşup galip geldikleri, Viyana kuşatmasında başarılı olamasalar da batıda Almanya, kuzeyde Polonya’ya kadar uzanan bir bölgeye 150 sene boyunca hâkim oldukları aktarılmaktadır. Aynı kitapta Osmanlıların Orta Doğu fetihleri anlatıldıktan sonra "Türk Sultanı bundan sonra halife olarak kabul edildi; o İslam dinîne inanan herkesin lideriydi" 
denmekte ve Arap ülkelerini almasının I. Selim’i halife makamına yükselttiğine işaret edilmektedir. ${ }^{11}$

Diğer eski ve yeni kitaplarda da benzer olay anlatıları mevcuttur; ${ }^{12}$ ancak 1980'ler ve 90'larda yayınlanmış kimi kitaplarda ilkin Paul Wittek'in ortaya attığı, literatürde uzun süre tesirli olsa da son dönemlerde sorgulanmaya başlanmış gaza tezinin etkileri de gözlemlenmektedir. ${ }^{13} 1987$ tarihli Toldot Yisrael veha-Amim'de Osmanlı Beyliği'ni savaşçı Türk boylarından birinin lideri olan Osman’ın kurduğu, Türklerin İran'ın doğusundaki anayurtlarından hareketle batıya doğru fetih seferlerine çıktıkları ve İslam diyarlarına girmelerinin ardından İslamiyet'i kabul ederek hızla "mutaassıp Müslümanlara” dönüştükleri belirtilmektedir. Ardından da "O zamandan itibaren Türkler kendilerini özellikle Hristiyan Bizans İmparatorluğu’na karşı İslami 'kutsal savaş' (cihad) için çalışan kimseler olarak görüyorlardı. Merkezlerini Anadolu olarak belirlediler ve Osmanlı Beyliği’ni de orada kurdular" denmektedir. ${ }^{14}$

Bunun gibi 1998 tarihli Mi-Dor le-Dor kitabında da Moğol İmparatorluğu parçalandıktan sonra başında Osman Bey'in bulunduğu yeni bir Türk boyunun Anadolu'da ortaya çıktığı ve Moğol devletinin kalıntıları ile Bizans’a saldırdığı belirtilmekte, ardından da şöyle devam edilmektedir: "Onun gayesi, beyliğinin sınırlarını genişletmek ve İslam dininin adını yüceltmekti. İslam’ın düşmanlarıyla savaş bir kutsal savaş (cihad) olarak değerlendiriliyordu ve bu inanç Osman'ın askerlerini savaş meydanında motive etmekteydi." Çok geçmeden dirayetli bir komutan ve ganimetin adil paylaşımına özen gösteren dürüst bir kişi olarak nam salan Osman'ın kendi boyundan olmayan pek çok Müslümanın da ona katıldığı ve böylece yeni bir İslam devleti olarak, kurucusunun adıyla anılan Osmanlı Devleti'nin tesis edildiği belirtilmektedir. Osman'ın ölümünden sonra oğullarının fetih seferlerini sürdürdüğü, Boğazları geçerek Yunanistan, Sırbistan, Yugoslavya ve Arnavutluk'u fethettikleri, bu şekilde dünyaya sadece Asya değil Avrupa'da da

11 Katz ve Hershko, Yisrael veha-Amim, s. 183-85.

12 Tcherikover, Historya Klalit, s. 90; Na'aman ve Kasher, Toldot Yemey ha-Beynayim, s. 462; Ziv, Ben-Sason ve Landau, Divrey ha-Yamim, s. 185; Tabibiyan, Masa' el ha-'Avar, s. 203; Katz ve Hershko, Yisrael veha-Amim, s. 183.

13 Paul Wittek, The Rise of the Ottoman Empire: Studies in the History of Turkey, ThirteenthFifteenth Centuries, ed. Colin Heywood (New York: Routledge, 2012). Wittek' in gaza tezi hakkındaki tartışmaların bir özeti için bkz. Heath W. Lowry, The Nature of the Early Ottoman State (Albany: State University of New York Press, 2003), s. 5-13.

14 Shavit, Toldot Yisrael veha-'Amim, s. 390. 
hüküm sürme niyetlerini gösterdikleri anlatılmaktadır. İslam ülkelerinin fethi anlatılırken de Osmanlıların İslam âlemini tıpkı İslam peygamberinin ve ondan sonra hüküm süren büyük halifelerin zamanında olduğu gibi tek bir hükümdarın idaresi altında birleştirmeye karar verdiği söylenmekte, ardından I. Selim’in fetihleri ele alınmaktadır. ${ }^{15}$

Böylece kitaplarda Osmanlı’nın kuruluş dönemi ve fetihleri anlatılırken nötr bir tutum takınıldığı gözlemlenmektedir; hatta Osman Bey’in dürüstlüğü ve komutan olarak becerileri övülmektedir. Fetihlerin arkasında yatan saikler tartışılırken de bir yandan tüm İslam âlemini halifeler döneminde olduğu gibi tek bir hükümdarın idaresi altında birleştirme arzusuna, diğer yandan da kimi kitaplarda olduğu gibi Paul Wittek'in teziyle uyum içinde gaza idealine işaret edilmektedir.

\subsection{Istanbul'un Fethi}

1987 tarihli Toldot Yisrael veha-'Amim, İstanbul'un fethi konusunun görece detaylı olarak işlendiği kitaplardan birisidir. Fethin Osmanlı İmparatorluğu için bir dönüm noktası olduğu belirtilen kitapta, askerlerin üç gün boyunca şehri soyup talan ettiği, hatta şehir sakinlerini acımasızca öldürdüğü kaydedilmektedir. Savaşın bitmesiyle birlikte Sultan II. Mehmed'in zaferle şehre girdiği, Aya Sofya'nın mozaiklerinin üstünü kapattırarak camiye çevirtip namaz kıldığı anlatılmaktadır. Ayrıca kitap Sultanın şehri Osmanlı İmparatorluğu'nun başkenti yaparken adını İstanbul şeklinde değiştirdiğini de öne sürmektedir. ${ }^{16}$ Her ne kadar Fatih'in şehrin adını değiştirdiği bilgisi yanlış olsa $\mathrm{da}^{17}$ tarihsel bir dönüm noktasının simgesi olarak isim değişikliğinin vurgulanması dikkat çekmektedir.

İstanbul'un fethi üzerine en ayrıntılı bilgi ise 1998 tarihli Mi-Dor le-Dor kitabında verilmektedir. Kitabın anlatısına göre II. Mehmed şehrin güçlü surlarını yıkmak için getirttiği Hristiyan uzmanlara toplar döktürtmüş, top gülleleri surları döverken Osmanlılar Bizanslıların kara tarafına diktikleri barikatları aşmışlardı. Kitap Sultanın İstanbul'u Osmanlı İmparatorluğu'nun başkenti yaptığını ve böylece Doğu Akdeniz'de bin yıl süren Hristiyan egemenliğinin sona erdiğini belirtmektedir. Ancak daha eski tarihli kitapta gördüğ̈̈müz, II. Mehmed'in şehrin ismini değiştirdiği konusundaki hatalı bilgi burada da tekrarlanmakta, ayrıca

15 Doron, Mi-Dor le-Dor, s. 9-10, 12.

16 Shavit, Toldot Yisrael veha-'Amim, s. 390-391. Aynı konuda bkz. Tabibiyan, Masa' el haAvar, s. 201.

17 Halil İnalcık, “Istanbul,” Encyclopedia of Islam, 2 ${ }^{\text {nd }}$ Edition, 1997, IV, s. 224. 
İstanbul kelimesine düşülen bir dipnotta yanlış bir etimolojiyle bu kelimenin Konstantinopolis isminin Türkçedeki bozulmuş hali olduğu da ileri sürülmektedir. ${ }^{18}$ Kitapta Aya Sofya’nın dönüşümüne de simgesel bir anlam yüklenmekte, Hristiyan tapınağı olarak kurulduktan sonra camiye çevrilmesi ve geçirdiği değişiklikler üzerinde durulmaktadır. ${ }^{19}$

İstanbul'un fethini işleyen kitaplar böylece söz konusu olayı bir dönüm noktası olarak vurgulama amacı ile bir yandan şehrin adında fetihten sonra gerçekleştiğini varsaydıkları değişikliğe, diğer yandan da Aya Sofya’nın camiye çevrilmesine vurgu yapmaktadır. Kimileri şehrin alınmasını izleyen yağmaya da eleştirel bir tavırla değinmektedir.

\subsection{Fetiblerin Sonuçları}

1959 tarihli Divrey ha-Yamim kitabında İstanbul'un fethinin Hristiyanlık açısından yol açtığı olumsuz sonuçlar vurgulanmakta, Doğu Roma İmparatorluğu’nun son bulmasıyla birlikte Batı ve Doğu Hristiyanlıkları arasında o zamana kadar mevcut bulunan bağın tamamen koptuğu, dolayısıyla Doğu Hristiyanlığına mensup ülkelerin kültürel gelişim yollarının kapandığı ifade edilmektedir. Fetih haberleriyle sarsılan Avrupa Hristiyanlarına, kendilerini bekleyen Türk tehlikesini önlemek için doğru düzgün bir ortak çaba göstermedikleri eleştirisi yöneltilmektedir. ${ }^{20}$ Ayrıca Osmanlı Türklerinin hemen tüm Doğu Akdeniz memleketlerine hâkim olmasının bu bölgeyle yapılan ticareti neredeyse tamamen durma noktasına getirdiği belirtildikten sonra şöyle denmektedir: "Gelir kaynakları kuruyup gitti ve girişimci, gayretli kimseler Doğu memleketlerine giden yollar arasında fanatik Türklerin egemen olduğu yollardan başkalarını aramaya koyuldular." ${ }^{21}$

1970’lerde yayınlanan kitaplarda da benzer vurgular mevcuttur. 1970 tarihli Historya Klalitte Avrupalı hükümdarlar Osmanlı'ya karşı birleşemedikleri için kınanmaktadır. "Hristiyan Avrupa, Türklerin fetih seferi karşısında çaresiz kalmıştı; bunun nedeni insan kaynaklarından yoksun olması değil, içerideki bölünmüşlüğü idi” saptamasında bulunulmakta ve ardından Papalığın yaptığı Haçlı Seferi çağrılarının, ortak düşmandan daha fazla birbirlerinden nefret eden Avrupa hükümdarlarını birleştirmekte başarısız kaldığı, Fransa’nın Osmanlı’yla

18 Doron, Mi-Dor le-Dor, s. 10.

19 Doron, Mi-Dor le-Dor, s. 11.

20 Ziv, Ben-Sason ve Landau, Divrey ha-Yamim, s. 184-85.

21 Ziv, Ben-Sason ve Landau, Divrey ha-Yamim, s. 268. 
Habsburg'a karşı işbirliği yaptığı eleştirel bir dille anlatılmaktadır. ${ }^{22} 1973$ tarihli Divrey ha-Yamim - ha-Zeman ha-Hadash kitabında ise Osmanlı Türklerinin Orta Doğu, Kuzey Afrika ve Balkanlara egemen olmasıyla birlikte ticaret ağlarının zarar gördüğg̈, bunun da fiyatların yükselmesine yol açtığı ve yeni yolların keşfedilmesi ihtiyacını doğurduğu belirtilmektedir. ${ }^{23} 1980$ 'ler ve sonrasında basılan kitaplarda ise fetihlerin sonuçları hakkında bu tür olumsuz veya farklı, olumlu değerlendirmelere yer verilmemektedir.

Avrupa ülkelerinin Osmanlı ilerleyişi karşısında birlik sergileyemedikleri için eleştirilmesi ve Osmanlı başarılarının buna bağlanması, önce İslam ve Osmanlılara karşı polemik niteliğinde eserlerde ortaya çıııp 1603'te Genel Türk Tarihi adlı kitabını yayınlayan Richard Knolles'tan itibaren Avrupa tarihyazımına da girmiş bir klişedir ve burada incelediğimiz İsrail tarih ders kitapları tarafından da devralındığı görülmektedir. ${ }^{24}$ Doğu Avrupa'nın Osmanlı idaresine geçmesinin buradaki halkları Batı Avrupa'nın kültürel gelişiminden koparttığının savunulması da aynı olumsuz bakışı yansıtmaktadır. Ayrıca bir kitapta gördüğümüz deyişiyle "fanatik Türkler"in Doğu Akdeniz’e hâkim olmasının buradaki ticaretin neredeyse tamamen kesilmesine yol açtı̆̆ iddiası da isabetli değildir ve Osmanlı yönetiminin Batılı tüccarların faaliyetine engel olmayıp tersine Akdeniz ticaretini teşvik edici politikalar izlediği bilinmektedir. ${ }^{25}$ Dolayısıyla bu iddianın modern tarih araştırmalarının verilerine dayalı olmayıp Türklerin "fanatikliği," yani dinî bağnazlığı klişesinden kaynaklandığı söylenebilir. Braude ve Lewis’ in işaret ettiği gibi, ${ }^{26}$ Müslüman fanatizmi, hoşgörüsüzlüğü teması, Rönesans döneminde kendilerini ilerleyen Osmanlı Türklerinin tehdidi altında hissettikleri zaman, onları Antik Yunan tarihyazımındaki Persler ve "Şark despotizmi" ile özdeşleştiren Avrupa hümanistlerinin bir ürünüydü. Türk sadece seküler anlamda bir karşıt olarak değil, başka dinden olup o din adına Hristiyanlara acımasızca davranan bir öteki olarak da konumlandırılıyordu. Bu tema daha sonra hoşgörünün bir değer olarak öne çıktığı Aydınlanma döneminde de canlandı ve Kiliseyi hoşgörüsüzlüğü yüzünden

22 Tcherikover, Historya Klalit, s. 90.

23 Ziv ve Toury, Divrey ha-Yamim, cilt 2, s. 14.

24 David Thomas ve John Chesworth (ed.), Christian-Muslim Relations: a Bibliographical History, vol. 8: Northern and Eastern Europe (1600-1700) (Boston: Brill, 2016), s. 133-34.

25 Bu konuda bir özet için bkz. Molly Greene, "Resurgent Islam: 1500-1700,” David Abulafia (ed.), The Mediterranean in History (London: Thames \& Hudson, 2003), s. 226-29.

26 Benjamin Braude ve Bernard Lewis, "Introduction,” B. Braude ve B. Lewis (ed.), Christians and Jews in the Ottoman Empire: The Functioning of a Plural Society, vol. 1: The Central Lands (New York: Holmes and Meier Publishers, 1982), s. 2. 
doğrudan eleştirmenin tehlikeli olduğu bir dönemde, dolaylı eleştiri için Müslüman hoşgörüsüzlüğü teması işlenmeye başlandı. Dolayısıyla dinî hoşgörüsüzlük ve bağnazlıkla özdeşleştirilen bir Türk imgesi Avrupa'da uzun süre egemen oldu. ${ }^{27}$ İsrail ders kitaplarındaki, bağnazlığından dolayı farklı dinden milletler ile ticarete yanaşmamış olduğu varsayılan fanatik Türk imgesinin de Avrupa'daki bu geleneksel klişenin kitaplara yansımasının bir ürünü olduğu söylenebilir.

\section{Kuruluştan Klasik Döneme Osmanlı Kurumları}

Kuruluştan klasik döneme Osmanlı kurumlarını anlatırken kitapların önemle üzerinde durduğu üç konunun ordu, merkeziyetçi yönetim yapısı ve gayrı-Müslimlerle ilgili düzenlemeler olduğu görülmektedir.

\subsection{Ordu}

Kitaplarda Osmanlı Devleti’nin kısa zamanda gerçekleştirdiği büyük fetihlerin ardında disiplinli ve savaşçı ruhlu ordularının yattığı vurgulanmaktadır. 1959 basımı Divrey ha-Yamim, Osmanlıların devşirme sistemine geçmeden önce dayandıkları Türkmen birlikleri hakkında bilgi veren tek kitaptır: "Eli silah tutan tüm Türkler Sultanın çağrısı üzerine sefere çıkmak zorundaydılar. Onların kolay hareket eden süvari ordusu, Hristiyan Avrupa halklarının ağır hareketli süvari ordusuna göre önemli bir güç avantajına sahipti.” Devşirme sistemi ve Yeniçeri ordusu hakkında ise kitapta şu bilgiler verilmektedir:

Hristiyan bir memleketin fethiyle birlikte Türkler Hristiyan ana babalardan henüz bebek yaştaki çocuklarının bir kısmını zorla alır ve onları genel olarak vatanlarından uzakta... İslam taassubu ve kâfirlerle savaş iştiyakı ile yetiştirirler, onlara yüksek düzeyde bir askeri eğitim verirlerdi. Bu "Yeniçeri" ordusu... askerî-dinî bir tarikat teşkil ediyordu ve hedefi Hristiyanlarla merhametsizce savaşmaktı.

Pasajda Yeniçerilerin dinî bir savaş yürütmek üzere yetiştirildiğinden dem vurulması ve bu anlamda Yeniçeri ocağının Batı'daki askeri tarikatlara benzetilmesi dikkat çekmektedir. ${ }^{28}$

27 Nedret Kuran-Burçoğlu, "A Glimpse at Various Stages of the Evolution of the Image of the

Turk in Europe: $15^{\text {th }}$ to $21^{\text {st }}$ Centuries," Mustafa Soykut (ed.), Historical Image of the Turk in Europe: $15^{\text {th }}$ Century to the Present (Istanbul: The Isis Press, 2003), s. 25.

28 Ziv, Ben-Sason ve Landau, Divrey ha-Yamim, s. 183. 
Bundan sonraki tarihlerde basılan kitaplarda ise Türkmenlere hiç değinilmeden ağırlıkla Yeniçeriler üzerinde durulmaktadır. 1972 basımı Toldot Yemey ha-Beynayim ba-Amim uv-Yisraelde, ordunun ana gövdesini hâlâ Türkmen birliklerinin oluşturduğu ve gelecekteki Yeniçeri ordusunun ancak ilk temellerinin atıldığı Orhan Bey dönemi hakkında, hatalı olarak "Orhan'ın başarısının sırrı, ordusunun özel düzenindeydi. Ordusunun omurgasını Yeniçeri ordusu oluşturuyordu” bilgisi verilmektedir. Devşirme sistemi bağlamında Yeniçerilerin küçük yaşta ailelerinden alınıp kendilerine özel okullarda askeri, siyasi ve dinî eğitim verildiği anlatılmakta ve "yüreklilikleri ve onları harekete geçiren savaşçı ruhlarıyla dünya çapında nam saldılar" denmektedir. ${ }^{29}$

Benzer vurgular daha yeni kitaplarda da mevcuttur. 1998 tarihli Mi-Dor le-Dor'da ilkin Yeniçeri ordusunun kuruluş sebebi ele alınmakta ve bu adım Osmanlıların çok sayıda fetih sonucunda salt kendilerine tabi Müslüman Türkler ile kurabileceklerinden daha büyük bir orduya ihtiyaç duymalarıyla açıklanmaktadır. Hristiyan ailelerden alınarak Müslüman yapılan ve özel askeri okullara gönderilen çocukların buralarda ağır idmanlardan geçmenin yanısıra İslam dininin temellerini ve özellikle cihadın önemini öğrendikleri, yetişkinliğe ulaştıklarında da bir aile kurmadan, kendilerini sırf orduya adayarak kale ve garnizonlarda yaşadıkları anlatılmaktadır. "Cesaret, dinî taassup ve savaşma coşkusu bakımından Yeniçerilerin üstüne yoktu ve bundan dolayı Osmanlı ordusunun öncü birliği olmuşlardı" saptamasında bulunulmaktadır. ${ }^{30}$

Aynı kitapta devşirme sistemi ve Yeniçeriler üzerine, "Bir Yeniçerinin Albümünden" başlıklı son derece ilginç bir alıştırma da yer almaktadır. Burada bir Yeniçerinin hayatından muhtelif aşamaları tasvir eden beş resim sıralanmakta ve girişte şöyle denmektedir: "Önünüzdeki beş resim, Bulgaristan' in Sofya şehrinden bir çocuk olan Yosif' in hikâyesini anlatmaktadır. Yosif 13 yaşını doldurduğunda anne babasından alındı..." Resimlerin altlarında Yosif' in ağzından her bir safhayı özetleyen başlıklar görülmektedir: "1. Anne babam beni askerlikten kurtarmak için yalvarsalar da görevliler bizi askere almayı sürdürüyor. 2. Askeri idmanlarda çok efor sarf ediyorum. 3. Vezir başmuhafızlığı pozisyonuna yükseldim. 4. Hocamın peşinden gölge gibi yürüyorum. 5. Sultanın yaverliğini yapıyorum.” Bunun ardından öğrencilerden Yosif' in hayat hikâyesini kaleme almaları ve Bulgaristan'daki babası veya ağabeyiyle karşılaşması hakkında kısa bir kompozisyon yazmaları istenmektedir. ${ }^{31}$

29 Na'aman ve Kasher, Toldot Yemey ha-Beynayim, s. 466.

30 Doron, Mi-Dor le-Dor, s. 9-10, 15.

31 Doron, Mi-Dor le-Dor, s. 16. Osmanlı orduları konusunda ayrıca bkz. Tcherikover, Historya 
İsrail ders kitaplarında devşirme sistemi işlenirken çocukların ebeveynlerinden zorla alınarak Hristiyanlarla savaşmaya can atan mutaassıp Müslümanlara dönüştürüldüğünün vurgulanması, sistemin zamanında uygulandığı Balkanlar'da bugün yayınlanan ders kitaplarının yaklaşımıyla koşutluk arz etmektedir. ${ }^{32}$ Ancak İsrail kitaplarındaki değerlendirmenin, Balkan kitaplarındakinden olumlu yönde ayrıştığı da görülmektedir. Öncelikle, Balkan kitaplarında devşirme sistemi hakkında kullanılan "kan vergisi" gibi olumsuz adlandırmalara, İsrail kitaplarında rastlanmamaktadır. Ayrıca Mi-Dor le-Dor'daki alıştırmada görüldüğü gibi son dönem kitaplarında devşirilen çocukların en yüksek mevkilere kadar yükselebildiği ve geride bıraktıkları aileleriyle görüşebildiği belirtilmektedir; hâlbuki bunlar Balkan kitaplarında geçiştirilen hususlardır. ${ }^{33}$ Ayrıca Balkan kitaplarında görülen, doğduğu topraklara dönerek Hristiyan ahaliye zulmeden tek boyutlu "acımasız Yeniçeri" imgesine nazaran İsrail kitaplarında daha olumlu bir imge sunulmakta, Yeniçerilerin disiplini, organizasyonu ve savaşçı ruhu övülerek Osmanlıların başarıları büyük oranda Yeniçeri ordusuna atfedilmektedir. Ancak diğer yandan Yeniçerilerin "İslam taassubu" ve Hristiyanlar ile cihad etme iştiyakına da vurgu yapılmaktadır ki burada kimi kitapların Kuruluş dönemiyle ilgili pasajlarında tesirini gördüğümüz gaza tezinin etkisi de hissedilmektedir. Sonuçta öğrencilere verilen mesaj; Osmanlı’nın coğrafi genişlemesinin ardında yalnızca dinî saikler yatan ve Hristiyan topraklarını fetih güdüsüyle hareket eden bir devlet olduğudur.

\section{2. İdare}

Osmanlı idari yapısına ilişkin olarak, daha eski kitaplardan 1970 basımı Historya Klalițte "[Osmanlı Devleti] her Şark devleti gibi mutlakıyetçilik ve bürokratizm ilkelerine dayanıyordu” saptaması yapılmaktadır. Ancak Sultanın otoritesinin pratikte genellikle gayet sınırlı olduğuna da dikkat çekilmektedir. "Acımasız bir despot" olarak nitelenen ${ }^{34}$ I. Selim gibi başına buyruk Sultanlara az

Klalit, s. 92; Toury ve Schmidt, Toldot ha-Amim, cilt 2, s. 6; Tabibiyan, Masa' el ha-Avar, s. 205; Katz ve Hershko, Yisrael veha-Amim, s. 183-85; Na'aman ve Kasher, Toldot Yemey ha-Beynayim, s. 466.

32 Karşılaştırma için bkz. Neriman Ersoy Hacısalihoğlu, "Bulgaristan Tarih Algısında ve Tarih Ders Kitaplarında Devşirme Sistemi ve Yeniçeriler,” Tarih Dergisi, 66 (2017), s. 129-54.

33 Gencer Özcan, "Balkan ve Karadeniz Ülkelerinde,” s. 436-37.

34 Feridun Emecen, bu pasajda “acımasız despot” olarak nitelenen I. Selim’in merhametsizlik ve kan dökücülüğ̈nün tarihyazımında ön plana çıkartılmasının, benzeri sertlikte davranışları olan VIII. Henry gibi müstebit krallara aşina 16. yüzyıl Avrupa kaynaklarının Osmanlılara genel bakışının bir yansıması olduğunu belirtir. Her ne kadar Osmanlı kaynaklarında da 
rastlandığı ve yönetimdeki işlevlerini genellikle memurlarının üstlendiği belirtilmektedir. Ardından da sadrazamın Sultan zayıf olduğu zamanlar bağımsızmışçasına kendi adına hüküm sürdügü, valilerin de merkezden ne kadar uzaklarsa o kadar bağımsız davrandıkları ve Sultana karşı yalnızca vergi ve asker toplamaktan sorumlu oldukları anlatılmaktadır. ${ }^{35}$

Daha sonraki dönemde, 1980 'ler ve 90'larda yayınlanmış kitapların yaklaşımı ise bundan çok farklıdır. Klasik dönemde Osmanlı yönetiminin merkeziyetçiliği vurgulanarak neredeyse ideal bir tablo çizilmekte, Osmanlıların başarılarının ardında yatan sebeplerden biri olarak ordularının yanısıra merkeziyetçi idari yapılarına işaret edilmektedir. 1987 tarihli Toldot Yisrael veha-'Amim'de Sultanın İmparatorluğun çeşitli yerlerine valiler gönderdiği ve kendisine sadık yerel yöneticilerin vergileri toplayıp bölgede yaşanan sıkıntıları merkeze bildirdiği anlatılmaktadır. ${ }^{36}$ Bu konu üzerinde en detaylı olarak 1998 tarihli Mi-Dor le-Dor kitabının "İmparatorluğun Başarılarının Arkasındaki Sırlar" başlıklı bölümünde durulmakta, "Osmanlılar, siyasi ve kültürel başarılarına salt askeri güçleri sayesinde değil, aynı zamanda yönetim metotları, yani merkeziyetçilik metodu sayesinde de eriştiler" denmektedir. Yönetimin başında Sultanın durduğu, onun sadrazamı atadığı, sadrazamın altında da yine çeşitli devlet pozisyonlarına atanan vezirler bulunduğu, keza Sultanın imparatorluğu eyalet, sancak ve kazalara ayırdığı, sancakların başındaki paşaların bölgelerinde olup bitenler hakkında Sultanı bilgilendirip devlet hazinesi için vergi topladıkları anlatılmakta ve şu sözlerle devam edilmektedir: "Sadrazamdan en küçük memura kadar yönetimdeki herkes Sultanın köleleri olarak değerlendirilir ve maaşlarını ondan alırlardı. Sultanın emirlerine karşı hareket eden veya görevlerinin ifasında başarısız olanlar, ağır cezalarla karşılaşır ve hatta bazen idam edilirlerdi." ${ }^{37}$

Böylece konuya değinen görece geç tarihli kitaplarda idealize edici bir yaklaşımla Osmanlı idaresinin merkeziyetçi niteliğine vurgu yapılırken daha eski kitaplarda Sultanın otoritesinin gerçekte çok daha kısıtlı olduğuna dikkat çekilmektedir.

sultanın acımasızlığı hakkında 16. yüzyıl Osmanlı tarihçisi Mustafa Âlînnin naklettikleri gibi anekdotlar bulunsa da bunların abartılı olduğuna ve daha çok yazarların kendi zamanlarının devlet adamlarına mesaj verme arzularından kaynaklandığına işaret eder. İlgili tartışma için bkz. Feridun M. Emecen, Yavuz Sultan Selim (İstanbul: Kapı Yayınları, 2016), s. 364-69.

35 Tcherikover, Historya Klalit, s. 93. Aynı tespit için bkz. Toury ve Schmidt, Toldot ha-Amim, cilt 2, s. 4.

36 Shavit, Toldot Yisrael veha-'Amim, s. 392.

37 Doron, Mi-Dor le-Dor, s. 13. 


\subsection{Zimmiler}

Birçok ders kitabında Osmanlı İmparatorluğu’nda gayrı-Müslimlere gösterilen hoşgörüden olumlu bir şekilde söz edilmektedir. 1959 basımı Divrey ha-Yamim'de gayrı-Müslim nüfus Sultana ağır bir yıllık vergi ödemeye zorlansa da kendilerine geniş bir özerklik tanındığı, ekonomik faaliyetlerine herhangi bir kısıtlama getirilmediği ve tıpkı Müslümanlar gibi can ve mal güvenliğine sahip oldukları belirtilmektedir. Çeşitli Hristiyan mezheplerine ve Yahudilere "elbette aşağı bir statüye tabi olarak" kendi inançlarına göre yaşamak için tam bir serbesti tanındığı, kimse dinini değiştirmeye zorlanmadığı gibi çok az kilisenin camiye çevrildiği not edilmektedir. ${ }^{38} \mathrm{Bu}$ yaklaşım, ilerleyen yılların kitaplarında da gözlemlenmektedir. 1970 basımı Historya Klalitte, konuya "Türkiye'deki Dinî Hoşgörü” başlıklı bir bölüm ayrılmışır. "Avrupa'da Türkler acımasız ve barbar olarak görülüyorlardı. Ancak en azından bir meselede Hristiyanlara üstündüler: diğer dinlere yaklaşımlarında" saptamasıyla konuya girilmektedir. Her ne kadar Hristiyan cemaatine cizye dayatılmakta ve Hristiyan çocuklar Yeniçeri ordusuna devşirilmekte olsalar da Türklerin Hristiyanlara ibadet edip kilise yapma hakkını tanıdıkları ve İstanbul'daki patriklik makamını Ortodoks Hristiyan âleminin başı olarak muhafaza ettikleri kaydedilmektedir. ${ }^{39}$

Daha yeni kitaplardan 1998 basımı Mi-Dor le-Dor'da da Osmanlıların başarısının atfedilebileceği faktörlerden biri olarak ordunun ve merkeziyetçi idarenin yanısıra "İmparatorluğun tüm sakinlerine gösterilen hoşgörü" sayılmakta, yabancı dil bilen meslek erbabı gayrı-Müslimlerin yüksek pozisyonlara atanabildiği, hatta sarayda görev alabildiği vurgulanmaktadır. Ünite sonundaki birincil kaynak metinleri arasında da "Osmanlı Hoşgörüsü” başlığı ile 15. yüzyıl sonunda yaşamış bir Yeniçerinin hatıratından alındığı belirtilen bir pasaj sunulmakta ve Osmanlıların bu hoşgörülü tutumuna örnek olarak gösterilmektedir. Pasajda fethedilmiş bölgelerdeki halkın süt gibi ürünlerini alıp da karşılığında ödeme yapmayan askerlerin nasıl cezalandırıldığı anlatılmaktadır. Ancak kitapta bu hoşgörünün ardında yatan saikler de sorgulanmakta ve asıl sebebinin İmparatorlukta bulunan çok sayıdaki gayrı-Müslim halkın isyan edebileceği korkusu olduğu öne sürülmektedir:

38 Ziv, Ben-Sason ve Landau, Divrey ha-Yamim, s. 185.

39 Tcherikover, Historya Klalit, s. 93. Bunun gibi Barnavi, Ha-Meah ha-20, s. 28'de de "Dev imparatorluk dinî hoşgörü bakımından üstün bir konumdaydı" saptamasında bulunulmaktadır. 
Osmanlı İmparatorluğu, çeşitli halklar ve farklı kültür ve inançların mensupları üzerinde hüküm sürerdi. Nüfusun çok renkli terkibi nedeniyle, imparatorluğun dört bir tarafında çıkabilecek ayaklanma ve isyanlardan korku duyuluyordu. Ayaklanma ve isyanların imparatorluğu içeriden parçalaması muhtemeldi; bundan dolayı Osmanlılar vatandaşlarına ve özellikle kitap ehline -Yahudi ve Hristiyanlara- büyük hoşgörüyle yaklaşıllardı. ${ }^{40}$

Bu sorgulayıcı yaklaşım, konuya son değinen kitaplardan 2006 tarihli Mahapekhah u-Geulah be-Yisrael uv-Amim'de daha da öne çıkmaktadır. Kitapta zimmi statüsü çerçevesinde gayrı-Müslimlere tanınan hoşgörü ve özerlik teslim edilmekle beraber statünün getirdiği kısıtlamalara ve ikinci sınıf vatandaş durumuna da vurgu yapılmaktadır. Söz konusu kısıtlamaların zimmileri Müslüman çoğunluktan ayırmak ve kamu alanını sınırlamasız kullanmalarının önüne geçmek amacını taşıdığı belirtilmektedir. ${ }^{41}$

$\mathrm{Bu}$ verilerin gösterdiği üzere, Podeh gibi Osmanlı İmparatorluğu'nda gayrı-Müslimlere gösterilen hoşgörüden kitaplarda söz edilmediğini savunmak mümkün değildir. Birçoğu konu üzerinde detaylı olarak durmaktadır. Ancak 1990'lar ve 2000'lerin kitaplarında hoşgörünün arkasında yatan hesaplara ve zimmi statüsünün getirdiği kısıtlama ve yükümlülüklere de vurgu yapıldığı görülmektedir.

İsrail ders kitaplarındaki “Osmanlı hoşgörüsü” klişesinden bahsederken bunun tam olarak ne anlama geldiği ve hangi kaynaklardan gelmiş olabileceği üzerinde durmakta da yarar vardır. Gördüğümüz gibi kitaplarda gayrı-Müslimlere yönelik kısıtlamalardan bahsedildiği ve özellikle yeni tarihli olanlarda zimmilerin ikincil statüsü ön plana çıkarıldığı için burada kastedilen "hoşgörü," gayrı-Müslimlere ayrımcılık uygulanmamasından ziyade baskı yapılmaması anlamında bir hoşgörüdür. Ancak her iki anlamıyla da kavram anakronik kalmaktadır, çünkü Benjamin Braude ve Bernard Lewis'in de işaret ettiği üzere, hoşgörü modern çağdan önce ne İslam ne Hristiyan toplumlarında özel değer atfedilen bir kavram değildi. Yazarlar, tıpkı daha önce hoşgörüsüzlük temasında gördüğümüz gibi, Müslüman hoşgörüsünün de Avrupa kökenli bir klişe olduğuna dikkat çekerler. İlk olarak Reformasyon döneminde, kimi Protestan yazarların Katoliklerin hoşgörüsüzlüğünü vurgulamak

40 Doron, Mi-Dor le-Dor, s. 13, 15.

41 Inbar, Mahapekhah u-Geulah, s. 16, 49-50. Hoşgörü konusunda ayrıca bkz. Katz ve Hershko, Yisrael veha-'Amim, s. 184; Toury ve Schmidt, Toldot ha-Amim, cilt 2, s. 16; Tabibiyan, Masa' el ha-'Avar, s. 203. 
için başvurduğu bir araç olarak ortaya çıkmış, daha sonra Aydınlanma sırasında yine o dönemin Avrupa toplumunu dolaylı olarak eleştirmek için kullanılmıştı. Klişenin yaygınlık kazanmasında Avrupalı Yahudiler de rol oynamış, Avrupa'da karşılaştıkları anti-Semitizme karşı Endülüs Müslümanlarının hoşgörüsünü idealize etmişlerdi; içlerinde tarihçi Heinrich Graetz gibi bu olumlu yaklaşımı Osmanlılara yansitanlar da vardis. ${ }^{42}$

Ancak Osmanlı bağlamında hoşgörü klişesinin başka kaynakları da mevcuttu. Osmanlılar İslam hukukunun zimmilere tanıdığı hakları tanımaktan başka Bizans sınır boylarında gayrı-Müslimlerle bir modus vivendi kurmayı başarmış ve hatta zaman zaman onlarla işbirliği de yapmışlardı. Ayrıca yeni fethettikleri şehirlerin ekonomik gelişmesi için gayri-Müslim nüfusun katkısına gereksinim olduğunu görerek onları buralarda zorunlu iskâna tabi tutmuşlardı. Dolayısıyla ilk dönemlerde Osmanlı şehirlerindeki gayrı-Müslim nüfus Müslüman nüfusa denk, hatta daha fazlaydı. Bu koşullar altında Osmanlılar pratik bir idari çözüm olarak gayri-Müslim cemaatlere hatırı sayılır bir özerklik alanı bırakmış ve onlarla ilişkilerini dinî liderleri vasıtasıyla yürütmüşlerdi. ${ }^{43}$ Laurent-Olivier Mallet'nin işaret ettiği gibi, bu tutumun "hoşgörü" olarak kodlanmasının Sefarad Yahudilerinin kolektif hafızasındaki, kimliklerini şekillendirmiş olan sürgün deneyimiyle de yakından ilgisi vardı: Osmanlı'nın bu pratik yaklaşımı çerçevesinde Sefarad Yahudilerini de topraklarında yerleşerek istedikleri mesleği icra etmek için cesaretlendirmesi ve cemaatlerini iç işlerinde özerk bırakması, İspanya'da gördükleri baskılar ve nihayetindeki zorunlu sürgün felaketiyle karşılaştırıldığında Sefaradların gözünde takdire şayan bir zıtlık oluşturmuş, Samuel Usque ve Eliyah Capsali gibi modern tarihçilerin de sıklıkla alıntıladığı o dönemin Yahudi yazarlarının övgüsünü toplamıştı. ${ }^{44}$ Dolayısıyla Avrupa’dan devralınma "Müslüman hoşgörüsü” temasının yanında Osmanlı’nın gayrı-Müslimlere karşı izlediği politikaların Sefaradların sürgün deneyimi ışığında algılanması da İsrail ders kitaplarındaki Osmanlı hoşgörüsü klişesine katkıda bulunmuş gözükmektedir.

42 Braude ve Lewis, "Introduction," s. 2-3.

43 Braude ve Lewis, "Introduction," s. 10-11, 16.

44 Mallet, Laurent-Olivier, La Turquie, Les Turcs et les Juifs : histoire, représentations, discours et strategies (Istanbul: Les Editions Isis, 2008), s. 101-102; ayrica bkz. Bernard Lewis, The Jews of Islam (Princeton: Princeton University Press, 1984), s. 135-39. 


\section{Gerileme Dönemi ve Bağımsızlık Hareketleri}

Bu bölümde Osmanlı İmparatorluğu’nun 16. yüzyıldan sonraki dönüşümlerini ve 19. yüzyılda Balkanlar'da gelişen isyanlar ve bağımsızlık hareketleri karşısındaki tepkisini kitapların nasıl ele aldığını inceleyeceğiz.

\subsection{Osmanlı Imparatorluğu’nun Gerilemesi}

Gerek eski gerek yeni kitaplarda Osmanlı İmparatorluğu’nun 16. yüzyıldan sonraki tarihi anlatılırken Osmanlı tarihyazımında 1970'lerin sonlarına tümüyle kadar egemen olan, ancak daha sonra özellikle Anglo-Sakson ülkelerdeki Osmanlı tarihi uzmanları tarafından sorgulanmaya başlanan gerileme paradigmasına ${ }^{45}$ bağlı kalındığı göze çarpmaktadır.

Görece eski ders kitaplarından 1973 basımı Toldot ha-'Amim ba-Zeman ha-Hadash, gerilemenin başlangıcının ardında yatan nedenleri en detaylı biçimde irdeleyen kitaptır. Kitapta gerilemenin ana sebebinin yönetim zafiyeti olduğu belirtilmektedir. Daha 17. yüzyılın başlarındayken Osmanlı İmparatorluğu’nun içyapısında sorunların baş gösterdiği, Sultanların bu sorunlara yoğunlaşmaktansa iktidarını kaybetme korkusuyla sürekli entrikalarla uğraştıkları anlatılmaktadır. Rüşvetin başta saray olmak üzere ülkenin tüm önemli mevkilerindeki memurlar arasında yaygın olduğu belirtilmektedir. Söz buradan yerel yönetimlere getirilerek uzak vilayetlerdeki yerel yöneticilerin Sultanın emirlerine kulak asmadıklarına işaret edilmektedir. Merkezi yönetimin ise yerel yöneticilere karşı biraz olsun gücünü pekiştirmek için onları birbirlerine düşürmeye çalıştığı belirtilmekte, daha ileri gidilerek "Yerel düzlemdeki zorbalıktan, bölgesel düzlemdeki savaşlardan ve merkezi yönetimin aczinden ibaret bu hatalı yöntemin sonuçları, bugün ülkemizde hâlâ net bir şekilde hissedilmektedir" tespiti yapılmaktadır. Askeri alanda Yeniçeri Ordusu'na devşirme yöntemiyle alımların durdurulduğu ve kimi askerlere alım-satım işleriyle uğraşma imkânı da tanındığı için imparatorluğun savunmasında başarısız kaldıkları

45 Gerileme paradigmasını sorgulayan başlıca çalışmalar için bkz. Roger Owen, "The Middle East in the Eighteenth Century - An 'Islamic' Society in Decline? A Critique of Gibb and Bowen's Islamic Society and the West," Bulletin (British Society for Middle Eastern Studies), 3, 2 (1976), s. 110-17; Douglas Howard, "Ottoman Historiography and the Literature of 'Decline' of the Sixteenth and Seventeenth Century," Journal of Asian History, 22 (1988), s. 52-77; Jane Hathaway, "Problems of Periodization in Ottoman History: The Fifteenth through the Eighteenth Centuries," The Turkish Studies Association Bulletin, 20 (1996), s. 25-31; Cemal Kafadar, "The Question of Ottoman Decline," Harvard Middle Eastern and Islamic Review, 4, 1-2 (1997-98), s. 30-75. 
belirtilmektedir. Aynı zamanda ordunun siyasi meselelere müdahil olmaya başladığı da kaydedilmektedir. Çöküş işaretlerinin ekonomi alanında da görüldüğü tespitiyle devam eden pasajda, bunun Osmanlı yönetiminin egemenliğindeki her yerde güç kazanan soygun ve sömürüden kaynaklandığı vurgulanmaktadır. Üretici ve çiftçilerin ürünlerine farklı yöntemlerle el konulduğu, hatta arazilerinin sık sık keyfi müsaderelere uğradığı anlatılmaktadır. Ticaretin de soygunculuktan ağır zarar gördüğü, yollar ve kanalların ihmale uğrayıp harap düştüğü belirtilmektedir. Dış kaynaklı her tür buluşu dine aykırı olduğu gerekçesiyle reddeden din adamlarının artan nüfuzu ve Yeniçerilerin şiddetli muhalefeti yüzünden Sultanların isteseler dahi geniş kapsamlı reformlar gerçekleştirip bu sürekli gerilemeyi durduracak güçte olmadıklarına dikkat çekilmektedir. ${ }^{46}$

Gerileme paradigmasının etkisi, son dönemlerin kitaplarında da görülmektedir. Üstelik bu kitaplarda işlenen konuların ağırlığı 1970’lerde basılanların tersine giderek daha fazla Yeniçağa kaydığı için ortaya daha da negatif bir Osmanlı imgesi çıkmaktadır. Gerileme devrini "İmparatorluğun Zayıflaması” başlığı alında işleyen 1998 tarihli Mi-Dor le-Dor'da, "17. yüzyılda Osmanlı İmparatorluğu gücünden kaybetmeye başladı. Güçlü orduya, merkeziyetçi yönetime ve Osmanlıların tebaalarına karşı sergilediği hoşgörülü tutuma karşın imparatorluk sürekli geriliyordu" sözleriyle konuya girilmektedir. 1683'teki başarısız II. Viyana kuşatmasının ardından Osmanlıları Avrupa'dan kovmak için Avusturya, Polonya, Rusya ve Venedik'in katıldığı bir "Kutsal İttifak" ın kurulduğu ve onları mağlup ettiği belirtilmektedir. $\mathrm{Bu}$ ve izleyen askeri yenilgilere koşut olarak ganimet ve vergilerden kaynaklanan gelirlerin de azaldığı ve neticede ürün fiyatları artarken paranın değerinin de düştüğü, Sultanların memur ve askerlerin maaşlarını ödemekte zorluk çekmeye başladığı ve bundan dolayı isyanların patlak verdiği anlatılmaktadır. Ardından gerilemenin askeri sebeplerinden idari sebeplerine geçilerek Muhteşem Süleyman döneminden sonra Sultan ve vezirlerin çoğunun öncekiler gibi yetenekli olmayıp tüm enerjilerini devlet işlerine vermektense "sarayın zevklerini" tercih ettikleri ve entrika ve yolsuzluklarla boğuştukları kaydedilmektedir. İmparatorluğun bu kötü durumunun diğer ülkeleri ondan toprak kopartmak konusunda cesaretlendirdiği belirtilmektedir. ${ }^{47}$

Benzeri şekilde 2006 tarihli Mahapekhah u-Geula be-Yisrael uv-Amim'de de 19. yüzyılda devleti krize sürükleyen faktörlerin dört maddelik kapsamlı bir analizi

46 Toury ve Schmidt, Toldot ha-Amim, cilt 2, s. 3-8.

47 Doron, Mi-Dor le-Dor, s. 13. 
sunulmaktadır: Sanayi devriminin olmaması, Sultanların ve diğer yöneticilerin katı idaresi, Avrupa güçlerinin menfaatleri ve milliyetçi isyanlar dalgası. İlk iki madde bağlamında askeriye ve ekonomide kullanılan eskimiş yöntemlerin Türkleri Avrupa'nın bu alanlardaki ilerlemesine ayak uydurmaktan alıkoyduğu ve yöneticilerin katı idare tarzının İmparatorluktaki değişik halklara baskı uygulanmasına, yönetime karşı ayaklanmalarına yol açtığı belirtilmektedir. Avrupa güçlerinin menfaatleri bağlamında, Rusya'nın rakibi durumundaki ülkeler İmparatorluğun bütünlüğünü korumayı oradaki çıkarlarına daha uygun görseler bile söz konusu çıkarları kollamalarının İmparatorluğun daha da zayıflamasına yol açtığı not edilmektedir. Nihayet İmparatorluğun Avrupa'da 19. yüzyılda egemen olan atmosferden beslenen bir milliyetçi isyanlar dalgası ile karşı karşıya kaldığına değinilmektedir. Tüm bu bileşenlerin bir araya gelerek "Şark Sorunu"nu doğurduğu ve Osmanlı İmparatorluğu’nun yaklaşan sonundan sonra ne olacağı sorusunu gündeme getirdiği kaydedilmektedir. ${ }^{48}$

Böylece eski yeni tüm kitaplarda Osmanlı İmparatorluğu'nun 16. yüzyıldan sonraki tarihi bir dönüşümler döneminden ziyade sürekli bir gerileme devri olarak değerlendirilmekte, Sultanlar bundan birinci derecede sorumlu tutulmakta, İmparatorluk için ordusundan ekonomisi ve kültürüne son derece karanlık bir tablo çizilmektedir. Özellikle de Osmanlı merkezi otoritesinin zayıflamasıyla birlikte vilayetlerde zorbalık, sömürü ve çatışmanın hâkim olduğu ileri sürülmektedir. Roger Owen'ın, Gibb ve Bowen'ın Islamic Society and the West kitabı hakkındaki değerlendirmesinde de işaret ettiği gibi bu tasvir, öncelikle Osmanlı'nın son yüzyıllarında geçirdiği dönüşümlere geleneksel Oryantalist bakışın bir yansımasıdır. Osmanlı'nın baştaki idari düzeninde gerçekleşen her türlü değişimi bozulma şeklinde değerlendiren bu yaklaşım, merkezi yönetimin vilayetler üzerindeki etkisinde meydana gelen her azalmayı da düzen ve asayişin zayıflamasına yol açan bir faktör olarak görmekteydi. Owen buna karşılık idari sistemdeki değişimlerin yeni koşullara esneklikle uyum sağlamak şeklinde de değerlendirilebileceğini ve tarihsel verilere yakından bakıldığında âyanın Filistin ve diğer bölgelerdeki yerel halka aslında merkezi yönetimden daha iyi bir güvenlik sunabilecek durumda olduğunu belirtiyor. ${ }^{49}$

48 Inbar, Mahapekhah u-Geulah, s. 81. Gerileme devrini ele alan diğer kitaplar için bkz. Kedem, Perekim be-Toldot Yisrael, s. 112-13; Zingrov ve Shahar, 'Am ve-'Olam, s. 20; Yigal Mish'ol, Ha-Leumiyut ha-Modernit, s. 80-81; Barnavi, Ha-Meah ha-20, s. 28; Tabibiyan, Masa' el ha-'Avar, s. 206; Tcherikover, Historya Klalit, s. 163-64.

49 Owen, "Middle East in the Eighteenth Century," s. 113-14. 
Cemal Kafadar'ın gözlemlediği gibi bu yaklaşımın kökleri, Avrupalıların Osmanlıya bakışında 17.-18. yüzyıllarda gerçekleşen dönüşüme kadar geri götürülebilir: O zamana kadar Osmanlı idaresini yabancılığına karşın sonuçta kendine has bir idare biçimi olarak gören Avrupalılar, bu yaklaşımı terk ederek Osmanlı’yı irrasyonel ve despotik bir güç olarak görmeye başlamışlardı. Osmanlı’nın İmparatorluk halkları ve kaynakları üzerindeki kontrolünü sırf kaba kuvvete dayanarak sürdürmeye çalıştığını varsayan bu yeni yaklaşıma göre, irrasyonalite ve despotizm kaçınılmaz olarak yolsuzluğa, sömürüye ve sosyal karmaşaya yol açacak, sonuç olarak da merkezi idare İmparatorluk halkları üzerindeki otoritesini kaybettiği gibi onlara güvenlik sağlamaktan da aciz bir duruma düşecekti. ${ }^{50}$ İşte kökleri 17. yüzyıla uzanan bu yaklaşım, tüm İsrail ders kitabı yazarlarınca da benimsenmiş gözükmektedir. Üstelik 1990'lar ve özellikle 2000'lerdeki kitapların gerileme paradigmasının çerçevesinden değerlendirdikleri bu dönem üzerinde ağılıklı olarak durmaları, sundukları Osmanlı imgesinin de daha negatif olmasına yol açmaktadır. Öte yandan "gerileme devri”"ne verilen bu ağılığın ardında Siyonist tarih söyleminin etkisi de yatmaktadır ki izleyen bölümlerde göreceğimiz bazı klişelere de tesir ettiği için bu faktörü sonuç bölümünde ele alacağız.

\section{2. İsyanlar ve Bağımsızlık Hareketleri}

Kitaplarda 19. yüzyılın başlarından itibaren Balkanlar'da çıkan isyanlar ve bağımsılılı hareketlerine de değinilmektedir. 1973 basımı Toldot ha-Amim ba-Zeman ha-Hadash'ta, 18. yüzyılda İmparatorluktaki genel kaos durumu ve gerilemenin sonucu olarak Hıristiyanların sıkıntı çekmeye başladığı ve yönetime karşı baş gösteren ilk Hıristiyan hareketlenmeleriyle birlikte Türklerin bazen çok sayıda insanın kıyımına varan zulümlerde bulunduğu belirtilmektedir. Bu mezalimin Hıristiyanlara yönelik dinî bir nefretten ziyade merkez yönetimin otoritesini koruma arzusundan kaynaklandığı, ancak Hıristiyanlar arasındaki huzursuzluğun artmasına engel olamadığı ve Hıristiyan halkların tam bağımsızlığa olan özlem ve isteklerinin giderek pekişip Osmanlı İmparatorluğu’nun parçalanmasına katkıda bulunduğu kaydedilmektedir. ${ }^{51}$

50 Kafadar, "Question of Ottoman Decline," s. 67-68. Buna ek olarak Douglas Howard gerileme temasının ilk olarak eski statükonun değişimine tanıklık eden 16.-17. yüzyıl Osmanlı yazarları tarafından gündeme getirildiğine ve bu yazarların Hammer'den Gibb ile Bowen'a kadar konu üzerinde duran birçok Avrupalı tarihçiyi de etkilediğine dikkat çeker, bkz. Howard, "Ottoman Historiography," s. 73-77.

51 Toury ve Schmidt, Toldot ha-'Amim, cilt 2, s. 6. 
Kitapta Yunan isyanının başında Yunanlıların Mora Yarımadası'nın kontrolünü ele geçirerek tüm Türk köylülerini katlettiği, bunun imparatorluğun diğer yerlerinde, özellikle de İstanbul'da yaşayan Rumların ve patriğin katledilmesiyle sonuçlandığı, Sakız Adası'ndaki Yunanlıların da öldürüldüğü belirtilmektedir. İngiltere ve Fransa'nın askeri ve diplomatik baskılarıyla Yunan toprağının Osmanlılardan "kurtarıldığı” ve 1832 yılında Yunanistan'ın bağımsızlığının tanındığı anlatılmaktadır. ${ }^{52} 19$. yüzyılın ikinci yarısındaki isyanlar bağlamında da "Türklerin zulüm politikası"nın Balkan halklarını isyana sevk ettiği belirtilmektedir. Düzenli Türk ordusu ile milislerin Bulgar isyanını "büyük bir acımasızlıkla" bastırdıkları ve Bulgar köylerinin tamamını yakıp yıkarak sakinlerini katlettikleri anlatılmaktadır. Daha sonra patlak veren Rus savaşı ve düzenlenen Berlin Kongresiyle de Balkan halklarının tam bağımsızlığına giden yolun açıldığı kaydedilmektedir. ${ }^{53}$

Yeni kitaplarda da bu olumsuz yaklaşımın aynı şekilde sürdüğü göze çarpmaktadır. 2006 tarihli Mahapekha u-Geula be-Yisrael uv-Amim ile 2008 basımı 'Olam Leumide bulunan ortak pasajda, "en meşhur milli mücadelelerden birisi" olarak tanımlanan Yunan isyanı anlatılırken gönüllülerin Avrupa’nın dört bir yanından Yunanlıların "özgürlüklerini geri almalarına yardım etmek" amacıyla buraya akın ettiği belirtilmektedir. "Yunanistan Türk boyunduruğundan kurtulan ilk ülke oldu. Onun başarılı mücadelesi, Avrupadaki tüm romantikleri etkiledi; Yunanistan'ın kurtuluşu hakkında şiirler yazdılar, resimler yaptılar, yazılar yazdılar ve Türk mezalimini kınadılar" cümleleriyle Yunan isyanının başarısı takdir edilmektedir. Aynı pasajda Osmanlı yönetiminin Bulgar başkaldırısını da "pek çok mezalimle" bastırdığı ve binlerce Bulgarı öldürdügü kaydedilmektedir. ${ }^{44}$ "Türklerin Bulgaristan'daki mezaliminden

52 Toury ve Schmidt, Toldot ha-Amim, cilt 2, s. 17-21.

53 Toury ve Schmidt, Toldot ha-'Amim, cilt 2, s. 174-77.

54 Bu kitaplarda değinilen Bulgar isyanı ve Osmanlılarca bastırılması, Bulgar tarihinde "Batak Katliamı” olarak bilinen olaydır ve Bulgaristan’ın bağımsızlığına giden yolda önemli bir adım olarak Bulgar tarihyazımı, ders kitapları ve Piotrowski'nin "Batak Katliamı" tablosu gibi resim ve fotoğraflar yoluyla kolektif benlikte yer etmiştir. İsrail ders kitaplarına da olay hakkındaki bu tarihyazımı geleneğinin yansıdığı görülmektedir. "Batak Katliamı”nn algılanması ve ulus/kolektif bellek inşası bakımından Bulgar tarihyazımındaki önemi için bkz. Vangelis Kechriotis, "History as a Public Claim and the Role of the Historian: Two Recent Debates Regarding the Ottoman Past in Greece and Bulgaria," E. Ginio ve K. Kaser (ed.), Ottoman Legacies in the Contemporary Mediterranean, the Balkans and the Middle East Compared (Jerusalem: The European Forum at the Hebrew University, 2013), s. 295-300; Sacit Kutlu, "Bulgar Kolektif Bellek İnşasında bir 'Hatırlama ve Unutma Yeri'," Toplumsal Tarih, 181 (2009), s. 33-39; Krzysztof Popek, "The Manipulation of Photographs by Dimitar Cavra and its Influence on the Creation of the Myth of the Batak Massacre (1876) in 
duyulan şok sonucunda" büyük güçlerin reformlar yapması için baskı altına aldıkları Osmanlı'nın buna direndiği, ancak Rus savaşını takiben Bulgaristan'ın özerkliğinin tanınmasıyla bağımsızlığa giden yolun açıldığı anlatılmaktadır. ${ }^{55}$

Kitaplardaki bu pasajlar değerlendirildiğinde, 19. yüzyılda baş gösteren isyanlar ve bağımsızlık hareketlerine değinen eski yeni tüm kitaplarda özgürlük mücadelesi veren Balkan halklarına zulmederek isyanları bastırmaya çalışan, son derece olumsuz bir Osmanlı portresi ortaya çımaktadır. İsyanların sebebi olarak Fransız Devrimiyle birlikte yayılmaya başlayan milliyetçilik düşüncesinin yanısıra Osmanlıların baskıcı politikaları da gösterilmekte, Balkan halklarının İmparatorluktan kopması olumlu bir gelişme olarak sunulmaktadır.

\section{Tanzimat ve II. Abdülhamid Dönemi}

İbranice kitaplarda çok ayrıntılı olmamakla birlikte Tanzimat dönemindeki reformlar ve bunların gayrı-Müslimlerin durumunda yol açtığı değişimler de konu edinilmektedir. ${ }^{56}$ Abdülhamid döneminin ise son derece olumsuz bir şekilde yansitıldığg görülmektedir.

\subsection{Tanzimat Dönemi Reformları ve Gayr-Müslimlere Etkileri}

Tanzimat reformları konusunda eski tarihli kitaplardan 1963 basımı Divrey ha-Yamim bilgi vermektedir. Çeşitli alanlardaki reformlar sıralandıktan sonra "Gerçekte ıslahatların çoğu yalnızca zahiri meselelerdeydi ve bir kısmı da hiç hayata geçirilmedi. Şeriat ilkesinden bir ayrılma olmadı ve şeriatın özellikle toplum ve aile meselelerindeki egemenliği sorgulanmadan kaldı” denmektedir. Bununla beraber, özellikle eğitim ve giyim alanlarında "muhafazakârlığın duvarlarında ilk önemli gediğin” açılmış olduğu da kabul edilmektedir. ${ }^{57}$

Bulgarian Historiography," Alicja Bemben, Rafał Borysławski, Justyna Jajszczok ve Jakub Gajda (ed.), Cryptohistories (Newcastle upon Tyne: Cambridge Scholars Publishing, 2015), s. 115-26. Olayın güncel Bulgar ders kitaplarındaki yansıması için bkz. Neriman ErsoyHacısalihoğlu, "Balkan ve Karadeniz Ülkelerinde,” s. 239; Piotrowski'nin tablosu hakkında bakınız aynı rapor, s. 18.

55 Inbar, Mahapekhah u-Geulah, s. 85-86; Bar-Hillel ve Inbar, 'Olam Leumi, s. 45-46.

56 Tanzimat öncesi reform çabalarına tek değinen kitap olan Toury ve Schmidt, Toldot ha'Amim, cilt 2, s. 21-22'de II. Mahmut'un reformlarının önünde engel olarak gördüğü Yeniçerileri yok ettikten sonra yeni bir ordu kurmanın yanısıra hukuk, giyim ve eğitim gibi alanlarda da reformlara giriştiği, ancak Mısır savaşı ve "tutucu dinî grupların agresif tepkisi" yüzünden büyük oranda başarısız kaldığı kaydedilmektedir.

57 Ziv, Ettinger ve Landau, Divrey ha-Yamim, s. 125-26. 
Tanzimat reformlarının dinî tutuculuk yüzünden büyük oranda başarısız kaldığına yapılan bu vurgu, son dönemlerde yayınlanmış kitaplarda da mevcuttur. 2006 tarihli Mahapekha u-Geula be-Yisrael uv-Amim'de, 1839'dan itibaren İmparatorluk bünyesindeki iç karmaşa ile büyük güçlerin baskısı neticesinde ve İmparatorluğun durumunu iyileştirip çöküşünü durdurmak amacıyla "Tanzimat" olarak bilinen bir dizi değişikliğin gerçekleştirilmeye başlandığı anlatılmaktadır. Ancak Avrupa modeline göre yürütüldüğü ve İmparatorluğa modernizmin getirilmesine odaklandığı belirtilen düzenlemelerin, uyandırdıkları güçlü dirençten dolayı ancak küçük bir kısmının başarılı olduğu vurgulanmaktadır. Kitaba göre direnç gösterenlerin başında "muhafazakâr güçler ve tüm imparatorluğa hâkim bir durumda bulunan dinî kurulu düzen" gelmekteydi. ${ }^{58}$

Aynı sav 2014 tarihli ve-Ele Toldot: Mesoret ve-Moderna'da, Tanzimat döneminde Yahudilerin ve diğer gayrı-Müslimlerin durumunda meydana gelen değişiklikler işlenirken de ileri sürülmektedir. Kitapta Osmanlı İmparatorluğu'nun, zayıflığını fırsat bilen Batılı güçlerin artan müdahalelerine set çekmek için İmparatorluktaki milletler nezdinde Osmanlı kimliğini teşvik etmek istediği ve bu amaçla gayrı-Müslimlerin durumuna yönelik bir dizi reform başlattığg belirtilmektedir. 1839 yılında Tanzimat Fermanı adıyla yayınlanan reform politikasının bütün İmparatorluk sakinlerinin mal mülklerinin korunup itibar ve huzurlarının sağlanması yönünde hükümler içerdiği, böylece teorik planda Müslümanların haiz olduğu haklara gayrı-Müslimlerin de eşit şartlarda sahip olmasının mümkün hale geldiği nakledilmektedir. 1856 yılında yayınlanan bir diğer fermanda da gayrı-Müslimlere eşit haklar sağlamak yönünde yeni adımlar atıldığı, ferman sonrasında az sayıdaki Hristiyan ve Yahudinin kamu görevlerine geldiği belirtilmektedir. Tanzimat sürecinin 1876 yilında her İmparatorluk vatandaşının kanun önündeki eşitliğini ve temel haklarını garanti eden bir anayasanın kabul edilmesiyle sona erdiği kaydedilmektedir. Ancak tüm bu düzenlemelerin çoğunun Müslüman halkın karşıtlığı yüzünden başarıya ulaşamadığı vurgulanmaktadır. ${ }^{59}$

Görüldüğü gibi, ele alınan dönem boyunca yayınlanmış kitaplarda Tanzimat reformları İmparatorluğun gerilemesini durdurup modernleştirmeye, gayr1-Müslimlere eşitlik tanımaya ve Batılı güçlerin müdahalelerini azaltmaya yönelik olumlu

58 Inbar, Mahapekhah u-Geulah, s. 50.

59 Orli, Ofir ve Schenkolewski, Ve-Ele Toldot, s. 204-5. Tanzimat'ın gayrı-Müslimler üzerindeki etkilerine değinen ve eşitliğin hayata geçirilemediğini vurgulayan diğer kitaplar için bkz. Inbar, Mahapekhah u-Geulah, s. 50; Barnavi, Ha-Meah ha-20, s. 33. 
adımlar olarak değerlendirilmekte, ancak dinî taassupla hareket eden muhafazakâr çevrelerin direnişinden dolayı reformların büyük kısmının kâğı̆ üzerinde kaldığı ve ancak eğitim ve giyim kuşam gibi bazı alanlarda kısmen etkili olabildikleri eleştirisi yöneltilmektedir.

\subsection{Abdülhamid Dönemi}

II. Abdülhamid dönemi hakkında müstakil bilgi veren tek kitap 1963 tarihli Divrey ha-Yamim'dir ve hayli olumsuz bir tablo çizmektedir. "Tipik bir taktisyen" olan Sultanın hükümeti teftişe gelen Batılı güçlerin temsilcilerinin bu girişimini, meclis kurulmasını da öngören liberal bir anayasa hazırlaması için Mithat Paşa’ya verdiği talimatla boşa çıkardığı, ardından da 1877-78 Rus savaşını gerekçe göstererek meclisi kapattığı, anayasayı yürürlükten kaldırdığı ve Mithat Paşa’yı sürgüne gönderip öldürttügü belirtilmektedir. Bunun ardından halkın üzerindeki baskının ağırlaşıı̆ı, Sultanın şüpheciliği seneden seneye arttıkça hafiyelerinin çoğalıp her yere ulaştığ 1 anlatılmakta ve bu zamanlarda İstanbul'a uğrayan bir seyyahın kaleminden "Şehir ahalisinin neredeyse yarısı, diğer yarısının faaliyetlerini jurnallemekle meşgul" sözleri nakledilmektedir. Liberal eğilimlere sahip olan kişilerin hapsedildiği, öldürüldüğü veya sürüldüğü, kitap ve gazetelerin yayın ve ithaline sansür uygulandığı ve ciddi kısıtlamalar getirildiği, yurtdışındaki sürgünlerin siyasi yayınlarını vatanlarına kaçak olarak sokmak zorunda kaldığı anlatılmaktadır. ${ }^{60}$ Böylece salt Batının baskısını azaltmak için anayasal meşruti bir rejimin kurulmasına razı olmuş görünse de ilk fırsatta liberal reformları rafa kaldırıp ülkeyi jurnal ve sansüre dayalı bir istibdat rejimiyle yöneten, muhalif veya tehlikeli addettiği kimseleri ölüme göndermekten çekinmeyen bir Abdülhamid portresi çizilmektedir. Sultanın döneminde maliye, ulaşım, posta, tarım, sanayi ve ticaret gibi alanlarda devam eden önemli reformlardan ise $^{61}$ söz edilmemektedir.

\section{Jön Türkler, 1908 Devrimi ve Yönetimdeki Politikaları}

İbranice kitaplarda Jön Türklere, gerçekleştirdikleri 1908 Devrimine ve yönetimi ele geçirdikten sonra izledikleri politikalara geniş yer ayrıldığı görülmektedir.

60 Ziv, Ettinger ve Landau, Divrey ha-Yamim, s. 126.

61 Stanford J. Shaw ve Ezel Kural Shaw, History of the Ottoman Empire and Modern Turkey, vol. 2: Reform, Revolution, and Republic: The Rise of Modern Turkey, 1808-1975 (Cambridge: Cambridge University Press, 1977), s. 221-38. 


\subsection{Jön Türk Hareketinin Doğuş ve Gelişimi, 1908 Devrimi}

Bir önceki bölümde II. Abdülhamid ve dönemi hakkında verdiği bilgileri incelediğimiz 1963 tarihli Divrey ha-Yamim kitabı, Jön Türk hareketinin "bu dönem için tipik olan zorbalık ve yolsuzluk emarelerine karşı bir tepki” olarak ortaya çıktığını belirtmektedir. ${ }^{62} 1973$ tarihli Toldot ha-'Amim ba-Zeman ha-Hadash'ta da bu olumsuzluklara karşı çıkan Jön Türklerin Osmanlı İmparatorluğu’nun yapısı ve yönetiminde köklü değişiklikler yaparak Türkiye’nin imajını düzeltmeyi ve onu Avrupa modeline göre modern bir ülkeye dönüştürmeyi istedikleri vurgulanmaktadır. Bu doğrultuda İttihat ve Terakki Cemiyeti'ni kurarak parlamenter yönetim, dinvicdan hürriyeti ve ifade özgürlüğü öngören 1876 anayasasının tekrar yürürlüğe konması talebinde bulundukları kaydedilmektedir. 1908'de Makedonya'daki orduyla İstanbul'a yürüme hazırlıkları karşısında Abdülhamid'in bu talepleri kabullenmek zorunda kaldığı, giriştiği başarısız karşı-devrimin ardından tahttan indirilince de Jön Türk iktidarının sağlamlaştı̆̆ı belirtilmektedir. ${ }^{63}$

Eski kitaplardaki bu anlatımın yenilerinde de sürdüğü görülmektedir. 1999 basımı ha-'Olam veha-Yehudim ba-Dorot ha-Aharonim'de, II. Abdülhamid'in 1876 Anayasasını yürürlükten kaldırarak ülkeyi demir yumrukla yönetmeye başladığı, yönetime karşı kalkışmaları sertlikle bastırdığı ve vergileri arttırdığı, bu baskıların karşısında askeriyedeki öğrenciler ile Avrupa’da yaşayan Türklerin "İttihat ve Terakki" şiarıyla "Jön Türkler" adı altında örgütlendiği anlatılmaktadır. Jön Türklerin 1908 yllında isyan başlatarak Sultan Abdülhamid'den ülkeyi anayasaya göre yönetmesini talep ettikleri, başta talebi kabul eden Sultan sözünden cayınca da yerine kardeşini geçirerek yönetimin dizginlerini ele aldıkları nakledilmektedir. ${ }^{64}$

Böylece eski yeni tüm kitaplarda Jön Türk hareketi Abdülhamid döneminin siyasi ve ekonomik baskılarına karşı doğan haklı tepkinin bir sonucu olarak kabul edilmekte, Jön Türklerin liberal bir meşrutiyet rejimi kurma planları olumlu karşılanmaktadır. Ancak yönetimdeki uygulamalarına karşı kitapların tavrı göreceğimiz gibi hayli farklıdır.

62 Ziv, Ettinger ve Landau, Divrey ha-Yamim, s. 127. Yeni kitaplarda yer alan benzeri bir açıklama için bkz. Inbar, Mahapekhah u-Geulah, s. 87-88.

63 Toury ve Schmidt, Toldot ha-Amim, cilt 2, s. 241.

64 Domkeh, Ha-'Olam veha-Yehudim, s. 45. 


\subsection{Jön Türklerin Yönetimdeki Politikalarn}

Ders kitaplarında Jön Türklerin yönetimi ele geçirdikten sonra izlediği politikalar son derece olumsuz bir şekilde değerlendirilmekte, özellikle İmparatorluğun Türkler dışındaki nüfusuna karşı tavırları eleştiri konusu yapılmaktadır.

İttihatçıların bu politikalarını en derinlemesine ve nedenlerini de tartışarak işleyen kitap, 1963 tarihli Divrey ha-Yamim'dir. Kitapta İttihatçlların ülkenin geleceğinden duydukları kaygı ve kendi konumlarını sağlamlaştırma ihtiyacı içinde reformlara giriştikleri, ancak Türk olmayan unsurları bu reformların önünde bir engel olarak gördükleri için onların önemli pozisyonlardaki temsilcilerini Türkler ile değiştirdikleri kaydedilmektedir. Türk milliyetçiliğiyle Pantürkizm’in İttihat ve Terakki saflarında giderek daha fazla revaç bularak Osmanlıcılığın ve Panislamizm'in yerini aldığı belirtilmektedir. Türk unsurunu hayatın tüm alanlarına hâkim kılma isteğinin İttihatçıların "sert ve zaman zaman zalimane yönetim şekline" de damgasını vurduğu ve İmparatorluktaki Araplar gibi halkları Türklere karşı kışkırttığı söylenmektedir. ${ }^{65}$

Benzer biçimde 1973 tarihli Toldot ha-Amim ba-Zeman ha-Hadash'ta da Jön Türklerin liberal bir anayasa hedefi gütmeleri ile İmparatorluk nüfusu içerisinde Türklerin egemen konumda olmasını savunmaları arasındaki çelişkiye dikkat çekilmekte ve devrimin sonuçlarının bu yüzden akim kaldığı, reformların başarıya ulaşamadığı belirtilmektedir. Jön Türklerin İmparatorluk topraklarında Türklerin üstünlüğünü gözettiği ve nüfusun geri kalanını yönetime ortak etmeye hevesli olmadıkları, Araplar ve Hıristiyanlara karşı "geleneksel zulüm politikalarını” sürdürdükleri ve "İttihat ve Terakki” sloganının boş sözlerden ibaret kaldığı ileri sürülmektedir. ${ }^{66}$

Daha yeni kitaplarda da Jön Türklerin politikalarına yönelik bu olumsuz tavrın aynı keskinlikte olmasa da sürdüğü gözlemlenmektedir. 1999 basımı ha-'Olam veha-Yehudim ba-Dorot ha-Aharonim'de ilkin bir umut kaynağı gibi görünen Jön Türklerin siyasi ve ekonomik hakların genişletileceği vaadinde bulundukları, ancak İmparatorluğun bütünlüğünü korumak amacıyla merkeziyetçi yönetime, Türk milliyetçiliğine ve Türk dilinin yaygınlaşmasına ağıllık verdikleri belirtilmektedir. ${ }^{67}$

65 Ziv, Ettinger ve Landau, Divrey ha-Yamim, s. 128-29.

66 Toury ve Schmidt, Toldot ha-Amim, cilt 2, s. 241-42. Benzeri bir anlatım için bkz. Ziv ve Toury, Divrey ha-Yamim, cilt 2, s. 45.

67 Domkeh, Ha-'Olam veha-Yehudim, s. 45. Aynı yönde bir değerlendirme için bkz. Domkeh, Urbach ve Goldberg, Ha-Leumiyut, s. 40. 
Böylece eski yeni tüm kitaplarda İttihatçıların İmparatorlukta yaşayan Türkler dışındaki nüfusa yönelik politikaları etnosentrik ve baskıcı oldukları gerekçesiyle eleştirilmekte, merkezileşme arzusu ve milliyetçi-Pantürkist ideolojinin etkisiyle açılanan bu politikaların Jön Türklerin liberal ve eşitlikçi bir anayasal düzen kurma vaatlerine ters düştüğü vurgulanmaktadır. Jön Türklerin herkes için özgürlük vaatleriyle Abdülhamit yönetimini devirdikten sonra baskıcı, Türkleştirmeci, İmparatorluktaki diğer Müslüman ve gayrı-Müslim halkların haklarını tanımayan bir politika benimsedikleri ve hayal kırıklığına uğrayan bu halkların isyan etmesine yol açtıkları argümanı, İsrail gibi Osmanlı bakiyesi topraklarda kurulmuş olan Balkan ülkelerinin tarih ders kitaplarında da mevcuttur. ${ }^{68}$ Söz konusu argüman, o ülkelerin ders kitaplarında Balkan İttifakını, Balkan Savaşlarını ve Osmanlı'dan geri kalan Rumeli topraklarının da kopartılmasını meşrulaştırıı bir işlev üstlendiği gibi İsrail kitaplarında da Suriye ve Filistin'in Osmanlı İmparatorluğu’ndan kopartılmasını ve bu süreçte bölgedeki kimi Araplar ile Yahudilerin İngilizler ile ittifak yapmasını meşrulaştırıcı bir işlev görmektedir.

\section{I. Dünya Savaşı Sırasında Osmanlı İmparatorluğu}

Kitaplarda I. Dünya Savaşı anlatılırken Osmanlı İmparatorluğu’nun savaştaki faaliyetleri hakkında da kimi bilgiler verilmekte, Ermeni olaylarına, Çanakkale Savaşı'na ve nihai yenilgiyi getiren, İngiltere'nin Filistin cephesindeki ilerleyişine değinilmektedir.

\subsection{Ermeni Olaylarn}

I. Dünya Savaşı sırasındaki Ermeni olaylarından müstakil olarak bahseden üç kitap tespit edilmiştir; bunların ilki 1963, diğer ikisi ise 2014 tarihlidir. ${ }^{69}$ İlkinde olaylar için herhangi bir tanımlama kullanılmazken ikincisinde "etnik temizlik," üçüncüsünde doğrudan "soykırım” terimleri kullanılmaktadır. 1963 tarihli Divrey

68 Mehmet Hacısalihoğlu, "II. Meşrutiyetin Balkan Ülkelerinde Algılanması ve Jön Türk İmajı,” 100. Yilında II. Meşrutiyet; Gelenek ve Değişim Ekseninde Türk Modernleşmesi Uluslararası Sempozyumu, ed. Zekeriya Kurşun, Cemil Öztürk, Yasemin Tümer Erdem, Arzu M. Nurdoğan (Istanbul: Marmara Üniversitesi Yayınları, 2009), s. 554-55.

69 Savaş öncesinde, II. Abdülhamid dönemindeki Ermeni olaylarına değinen kitaplar için bkz. Ziv, Ettinger ve Landau, Divrey ha-Yamim, s. 126; Zingrov ve Shahar, 'Am ve-'Olam, s. 121-22. İkinci kitapta Ermenilerin sadakatinden şüphelenmeye başlayan Sultanın önayak olmasıyla “Osmanlı İmparatorluğu’ndaki Ermeni cemaatlerine karşı aralıksız pogromlar, yağmalar ve katliamlar gerçekleştirildiği” savunulmakta ve büyük güçlerin kayıtsızlığı eleştirilmektedir. 
ha-Yamim, önceki bölümde Jön Türklerin politikalarına yönelttiğini gördüğümüz eleştirilere devamla Türklerin savaştaki mağlubiyetlerinin en önemli nedenlerinden birisinin de yöneticilerin Türk olmayan İmparatorluk halklarının ve özellikle de Ermenilerin dostluk ve sadakatlerini kazanmaktaki başarısızlığı olduğunu belirtmektedir. Osmanlı İmparatorluğu’ndaki varlıklı Ermeniler savaşta Osmanlı İmparatorluğu'nu desteklerken Kafkasyảnın Ruslara ait kısmında ikamet eden Ermeni Katoğikosu'nun Rus Çarını tüm Ermenilerin hamisi ilan ettiği kaydedilmektedir. İstanbul'da ve Osmanlı İmparatorluğu’nun batı bölümündeki şehirlerde yaşayan Ermeniler seferberlik emrine uysalar da İmparatorluğun doğu kesimindeki Ermenilerin ayaklanarak Müslümanları öldürdükleri ve 1915 Nisanı’nda Van'da bir Ermeni devletinin kurulduğunu ilan ettikleri, Türk yönetiminin ise buna cevaben Ermenilerin askeri üsler ile nakil hatlarından uzaklaştırılması ve ordudakilerin de cephe gerisi görevlere geçirilmesi emrini verdiği kaydedilmektedir. Bu emirler üzerine pek çok Ermeninin iskân edilecekleri bölgeler hakkında kendilerine bilgi verilmeden yaşadıkları yerlerden çıkartıldıkları ve tahammülfersa koşullarda Suriye’ye yayan göç ettikleri anlatılmaktadır. I. Dünya Savaşı başladığı zaman Osmanlı İmparatorluğu’nda bulunan 1,5 milyon Ermeni'den yaklaşık bir milyonunun 1916-1917 senelerinde yollarda sürünmekten, kıtlıktan ve Türkler ile Kürtlerin sürülen Ermeni konvoylarına saldırmalarından dolayı hayatını kaybettiği belirtilmektedir. ${ }^{70}$

2014 tarihli ve-Ele Toldot: Mesoret ve-Moderna'da ise Ermeni olayları "Savaş Sırasında Etnik Temizlik Yapıldı” başlığı altında ele alınmaktadır. Kitapta I. Dünya Savaşı'nın çetin ve acımasız olaylarından birisinin de etnik temizlik olduğu belirtildikten sonra terim "belli bir etnik grubu belli bir bölgeden uzaklaştırmak ve aynı bölgeyi başka bir etnik gruba vermek amacıyla yapılan katliam veya sürgünler” şeklinde tanımlanmaktadır. Savaş sırasında özellikle ağır bir etnik temizliğin de Ermeni halkına yapıldığı notuyla söz Ermeni olaylarına getirilmektedir. I. Dünya Savaşı'nda bazı Ermeniler Osmanlı İmparatorluğu'nu desteklerken diğerlerinin bağımsızlıklarını kazanmakta yardımını görecekleri ümidiyle Rusya’ya destek verdikleri, bu yüzden Osmanlı ordusu Rusya karşısında birkaç yenilgi alınca tüm Ermenilerin ihanetle suçlanıp başarısızlıktan sorumlu tutulduğu anlatılmaktadır. Bunun akabinde, 24 Nisan 1915 'te Türk yetkililerinin (orijinal metinde koyu vurguyla) “Ermeni halkına karşı bir katliam seferi” ne girişerek 1915-1916 yıllarında sürgün ve kıyımlar gerçekleştirdikleri, kurban sayısının tam bilinmemekle beraber yüzbinler ile iki milyon arasında değiştiği nakledilmektedir. ${ }^{71}$

70 Ziv, Ettinger ve Landau, Divrey ha-Yamim, s. 209.

71 Orli, Ofir ve Schenkolewski, Ve-Ele Toldot, s. 121. 


\section{4 tarihli ha-Leumiyut be-Yisrael uv-'Amim: Reşit ha-Derekh 'ad 1920} kitabında ise Ermeni olayları hakkındaki bilgi Nili casusluk teşkilatı üzerine olan bölümü takiben, "Ermeni Soykırımı" başlıklı bir kutu içerisinde verilmektedir. Metinde Ermenilerin daha I. Dünya Savaşı çıkmadan önce katliamlara maruz kaldığı kaydedildikten sonra "Savaş sırasında (ve sonrasında) Osmanlılar Ermenilere kıyım yaptılar ve onları kitleler halinde Suriye çölüne doğru tehcir ettiler. Pek çoğu hayatta kalmak için gerekli koşullardan yoksun olan kamplarda toplanan Ermenilere karşı izlenen bu kitlesel kıyım ve tehcir politikası, savaş sırasında Ermenilerin Osmanlı İmparatorluğu’na karşı çalıştıkları ve Rusya'ya yardım ettikleri savıyla yürürlüğe konmuştu" denmektedir. Pasajın sonunda da 1 ila 1,5 milyon Ermeni'nin Osmanlı yetkililerinin kıyımlarından dolayı hayatını kaybettiği belirtilmektedir. ${ }^{72}$

Bu tabloya bakıldığında ders kitaplarının Ermeni olayları konusuna yaklaşımının 1960’lardan günümüze kayda değer bir dönüşüm geçirdiğini söylemek mümkün görünmektedir. Eski tarihli kitapta bir milyon Ermeninin hayatını kaybettiği söylense de ölümler yöneticilerin kasıtlı eylemlerinden ziyade tehcir sırasındaki çetin koşullar ile Müslüman nüfusun saldırılarına atfedilmekte, soykırım veya etnik temizlik gibi terimlerden kaçınılmaktadır. Yeni kitaplarda ise bu terimler açıkça kullanıldığı gibi ölümlerden doğrudan Türk yetkililerinin yaptığı söylenen kıyımlar sorumlu tutulmaktadır. Ayrıca kitapların ikisinde bazı Ermenilerin Rusyàya destek verdiği ve ayaklandığı ifade edilirken diğer yeni tarihli kitapta buna değinilmemesi de dikkat çekmektedir. Türkiye'nin bulunduğu bölgede yer alan diğer ülkelerin güncel ders kitaplarıyla karşılaştırıldığında, Ermenilerin başlıca "öteki" olarak konumlandırıldığı Azerbeycan kitapları dışında Boşnak, Hırvat, Yunan ve Rus kitaplarında da güncel İsrail kitaplarıyla aynı yaklaşımın benimsendiği ve Ermenilere uygulanan bir imha, soykırım ve/veya etnik temizlikten bahsedildiği görülmektedir. ${ }^{73} \mathrm{Bu}$ da İsrail kitaplarının konuya yaklaşımındaki değişimin, daha genel bir trendi takip ettiğini göstermektedir.

\section{2. Çanakkale Savaşı}

Çanakkale Savaşı üzerinde 1950'ler ve 60'larda yayınlanmış üç kitapta durulmakta, daha sonraki yılların kitaplarında ise bu konuya yer verilmemektedir. 1958

72 Kovarsky, Ha-Leumiyut, s. 186. Konuya müstakil olarak değinen bu üç kitap dışında 1990’larda yayınlanmış kitaplardan Naveh, ha-Meah ha-20, s. 11'de "Türkler Ermenilere karşı soykırım gerçekleştirdi” cümlesi ve Barnavi, $\mathrm{Ha}$-Meah ha-20, s. 72'de de "Ermeni soykırımının haberleri Eretz İsrail'e ulaşmış ve ciddi endişeler doğurmuştu” ibaresi yer almaktadır.

73 Bkz. "Balkan ve Karadeniz Ülkelerinde," s. 106-7, 133-34, 286-87, 385, 389, 407. 
tarihli Divrey ha-Yamimile 1967 tarihli Toldot ha-'Amim ba-Zeman ha-Hadash'ta görülen yaklaşım ile 1963 tarihli Divrey ha-Yamim kitabının yaklaşımı da birbirlerinden hayli farklıdır.

1958 basımı Divrey ha-Yamimile koşut, ${ }^{74}$ ancak daha detaylı bir anlatı sunan 1967 basımı Toldot ha-Amim ba-Zeman ha-Hadash'ta, güçlü bir İngiliz-Fransız donanmasının 1915 Martı'nda Çanakkale Boğazı'nı geçme girişiminde bulunduğu belirtilmektedir. Ancak sahildeki ilk mevzilerde bulunan bataryaların susturulmasına ve Boğazın mayınlardan temizlenmesine karşın donanma komutanının dört savaş gemisinin kaybedildiği gerekçesiyle harekâtı başarıya erişemeden durdurduğu vurgulanmaktadır. Pasajın devamında bu yenilginin ardından altmış bin kişilik bir ordunun Nisan sonunda Gelibolu’ya çıkartma yaparak önemli bir köprübaşı mevzisini ele geçirmeye muvaffak olduğu, ancak köprübaşının istenilen hızda genişletilememesinin Türklere müdafaa hatlarını düzenleme fırsatını sunduğu belirtilmektedir. Ağustos'taki ikinci bir çıkartmanın da Türkler tarafından durdurulduğu belirtilirken "gelecekte savaştan sonra Türkiye’nin lideri olarak yükselecek Kemal Paşa ilk kez üstün başarı sergiledi” denmektedir. ${ }^{75}$ Böylece kitapta Çanakkale savaşı büyük oranda Britanya gözünden aktarılmakta, Osmanlılar Mustafa Kemal'e yapılan kısa değini dışında etkin bir özne rolünde görülmemekte, deniz harekâtının başarısızlığı filo komutanının vakitsiz çekilme kararına bağlanırken kara harekâtının başarısızlı̆̆ı da Türklerin direnişi kadar müttefiklerin yavaş kalarak onlara zaman bırakmasıyla açıklanmaktadır.

Buna karşılık 1963 tarihli Divrey ha-Yamim'in anlatımı ise hayli farklıdır ve Türklerle Alman müttefikleri burada azimli ve becerikli direnişleriyle İtilaf Devletlerine set çeken gerçek özneler olarak boy göstermektedir. Kitapta İtilaf Devletlerinin Gelibolu'daki yenilgisinin sebepleri arasında yeteri kadar kuvvet toplanamaması da sayılmakta, ancak başarısızlığın asıl Türklerle Almanların sıkı işbirlikleri, çetin mücadele güçleri ve gerçekçi taktikleri sayesinde müttefik çıkartma kuvvetlerine çok sayıda kayıp verdirmelerinden kaynaklandığı belirtilmektedir. ${ }^{76}$

Çanakkale Savaşı' na değinen üç kitaptan ikisi böylece savaşı İtilaf devletlerinin perspektifinden aktarmakta ve bu devletlerin yaşadığı yenilgiyi büyük oranda kendi hatalarına bağlamaktadır; Osmanlıların ve Alman müttefiklerinin direnişine bu yenilgide başrolü biçen ise tek bir kitaptır.

74 Ziv ve Toury, Divrey ha-Yamim, cilt 2, s. 114.

75 Toury ve Schmidt, Toldot ha-Amim, cilt 3, s. 16-18.

76 Ziv, Ettinger ve Landau, Divrey ha-Yamim, s. 208. 


\subsection{Yenilgi ve Mondros Mütarekesi}

Kitaplarda Osmanlı İmparatorluğu'na savaşta yenilgiyi getiren kritik gelişme olarak İngiliz ordusunun Filistin'deki ilerleyişi üzerinde durulmaktadır. 1963 basımı Divrey ha-Yamim'de, İngilizlerin Arapların da yardımıyla kuzeye doğru ilerleyişleri nakledilirken "Türk kuvvetleri ancak Halep şehri yakınında tutundular; daha o zamandan Gelibolu çatışmalarında ve Türk cephesinde üstün başarı sergilemiş olan Mustafa Kemal adlı bir subayın kumandasındaydılar” denmektedir. Ancak Osmanlılar Avrupa cephesinde ağır darbeler yiyen Almanların yardımı olmadan mücadeleyi sürdüremedikleri için 30 Ekim 1918'de Mondros Mütarekesi'ni imzalamaya mecbur kaldıkları, böylece de toprakları yaklaşı 400 yıldır tüm Orta Doğu’yu kaplayan Osmanlı İmparatorluğu'nun son bulduğu belirtilmektedir. ${ }^{77}$

Yine aynı dönemin kitaplarından 1967 tarihli Toldot ha-'Amim ba-Zeman ha-Hadash'ta da İngilizler'in Irak cephesinde Musul'a kadar ilerlemelerine karşın sonucu asıl belirleyenin Filistin cephesinde daha geç gelen başarıları olduğu belirtilmektedir. Gazze'de Türklerin saldırıları ve Alman takviye kuvvetlerinin varışı yüzünden bir süre duraklayan İngiliz hücumunun, komutan Edmund Allenby'nin atanmasıyla tekrar ivme kazandığı ve Türk hatlarının yarıldığı anlatılmaktadır. ${ }^{78}$ Saldırının başlamasından iki hafta sonra Şam'ın alındığı, Ekim sonlarında Halep'in de düşmesinin ardından Türkiye’nin imzalamak zorunda kaldığı ateşkes antlaşmasıyla savaşın sona erdiği belirtilmektedir. ${ }^{79}$

Yeni kitapların anlatılarında da bundan farklı bir yaklaşım göze çarpmamaktadır. 2008 tarihli ha-Leumiyut: Reşit ha-Derekh'te Türkiye ve Almanya 1915-1916 yıllarında Mısır’ı almaya yönelik başarısız harekâtlar yürüttükten sonra 1917 boyunca Filistin'in bir savaş sahasına dönüştüğü, güçler dengesinin değişmesiyle beraber İngilizlerin Mısır'dan ilerleyerek 1918'de tüm Filistin'e egemen oldukları kaydedilmektedir. Aynı sayfada İngiliz ordusunun Filistin'deki ilerleyişini gösteren bir harita verilmekte, Osmanlı hatları hiç gösterilmediği için İngilizler karşılarında bir savunma gücü olmadan ilerliyormuş gibi bir görünüm ortaya çıkmaktadır. ${ }^{80}$

77 Ziv, Ettinger ve Landau, Divrey ha-Yamim, s. 214.

78 Toury ve Schmidt, Toldot ha-Amim, cilt 3, s. 58-59.

79 Toury ve Schmidt, Toldot ha-Amim, cilt 3, s. 66.

80 Domkeh, Urbach ve Goldberg, Ha-Leumiyut, s. 167. Benzer bir harita için bkz. Kovarsky, Ha-Leumiyut, s. 180. 
Böylece Çanakkale Savaşı'nda olduğu gibi Filistin cephesindeki çatışmaları anlatırken de eski yeni tüm kitaplar olayları daha ziyade İngiltere zaviyesinden aktarmakta ve bir kitapta Mustafa Kemal'e yapılan değini dışında Osmanlılardan karşıda direniş gösteren etkin bir özne olarak söz edilmemektedir.

\section{Sonuç ve Tartışma}

Elie Podeh’nin Osmanlı döneminin İsrail tarih ders kitaplarında ihmal edildiği yolundaki savının aksine, gördüğümüz gibi kitaplarda Osmanlı tarihinin çeşitli dönemleri hakkında detaylı bilgi verilmektedir. 1980 'ler ve 90 'larda basılmış kimi kitapların kuruluş dönemi ve fetihler konusundaki anlatımında bugün için tartışmalı gaza tezinin etkileri gözlemlenmekte, Osmanlılar ve orduları için cihad idealinin önemi vurgulanmaktadır. Aynı zamanda Osmanlıların tüm İslam âlemini halifeler dönemindeki gibi tek bir hükümdarın idaresi altında birleştirmek arzularından söz edilmektedir. Batıdaki fetihler bağlamında ise Hristiyan Avrupa Osmanlılar karşısında birlik halinde bir direniş sergileyemediği için eleştirilmekte, Osmanlı fetihlerinin Batı ve Doğu Avrupa halkları arasındaki bağlantıyı kopardığı ve Türklerin engelleyici politikalarından dolayı yeni ticaret yollarının bulunmasını zorunlu kıldığı belirtilmektedir.

Podeh'nin Osmanlı imgesinin 1990'lara kadar basılan kitaplarda son derece olumsuz olduğu, gayrı-Müslimlere gösterilen hoşgörü gibi olumlu noktalardan söz edilmediği, imgenin ancak 90’lardan itibaren bir miktar iyileşme gösterdiği yönündeki saptamalarının da yerinde olmadığı görülmüsstür. 1970’lerden 1990'lara kadar basılan kitaplarda klasik dönem Osmanlı İmparatorluğu disiplinli ve savaşçı ordusu, gayrı-Müslimlere karşı hoşgörüsü ve merkeziyetçi idaresi takdir edilerek son derece olumlu bir şekilde betimlenmektedir. Dahası, girişte işaret edildiği gibi tüm kitaplar Osmanlı tarihini gerileme paradigması çerçevesinde değerlendirdikleri ve üstelik 1990'larda basılan kitapların çoğu ile 2000'lerde basılan kitapların biri hariç hepsi 16. yüzyıldan sonraki döneme odaklandıkları için ortaya koydukları Osmanlı imgesi eski kitaplara nazaran daha olumsuzdur. Nitekim bu devirde Osmanlı İmparatorluğu Sultanların yetersizliği yüzünden merkezi yönetimin zayıfladığı, yerel yöneticilerin bildiğini okuduğu, çatışma ve anarşinin kol gezdiği, altyapının ihmale uğradığı, rüşvetin yaygınlaştığı, yozlaşan ordunun etkinliğini, sanayi devrimini kaçıran ekonominin de canlılığını kaybettiği bir ülke olarak tasvir edilmektedir. Bu koşullar alında Balkan halklarının isyanları haklı bulunmakta ve Osmanlı yönetiminin bu isyanları pek çok kıyım ve zulümle bastırmaya çalışı̆̆ğından söz edilmektedir. 
Eyal Naveh'nin de işaret ettiği gibi, İmparatorluğun son yüzyılındaki reform çabaları ve özellikle bu çerçevede gayrı-Müslimlere tanınan eşitlik de kitaplarda büyük oranda kâğıt üzerinde kalmış girişimler olarak değerlendirilmektedir. II. Abdülhamid dönemi son derece olumsuz bir yaklaşımla ele alınmakta, bu padişahın yönetiminin baskıcı yanları öne çıkartılırken döneminde modernleşmeye yönelik reformların sürdüğü gözardı edilmektedir. Jön Türklerin ortaya çıkışı ve 1908 Devrimi Abdülhamid'in politikalarına karşı doğan haklı bir tepkinin sonucu olarak takdim edilmekte, ancak onların da gayrı-Müslimlere eşitlik tanıyan liberal bir rejim kuracakları yönündeki beklentilerin çok geçmeden boşa çıktığı, tam tersine merkeziyetçi ve Türkler dışındaki tüm halklara karşı baskıcı politikalar benimsedikleri vurgulanmaktadır. I. Dünya Savaşı sırasındaki Ermeni olayları konusu eski kitaplarda Türkiye'nin resmi tarih tezlerine görece daha yakın bir şekilde anlatılırken son dönem kitaplarında doğrudan Osmanlı yetkilileri tarafından gerçekleştirilmiş bir etnik temizlik veya soykırımdan bahsedildiği görülmüştür. Aynı dönemdeki Çanakkale Savaşı'nı ve İngiliz ordusunun Filistin-Suriye seferini konu alan kitapların çoğu da olayları sadece İngiliz perspektifinden aktarmakta ve genellikle Osmanlılardan karşı taraftaki etkin bir özne olarak söz etmemektedir.

Bu bağlamda ele alınması gereken önemli bir soru, İsrail tarihyazımına egemen olan Osmanlı hakkındaki söylem ve algıların ders kitapları üzerinde nasıl ve ne kadar etkili olduğudur. Maurus Reinkowski, önde gelen İsrailli tarihçilerin hemen hepsinin eğitimlerini kısmen veya tamamen Batı'da tamamlamış olduğuna dikkat çekerek bu nedenle İsrail tarihçiliğinin Batılı ve özellikle Anglo-Sakson tarihyazımı geleneği ve akademik söylemleriyle uyum içinde olduğu tespitinde bulunur. Bunun bir sonucu olarak Batı kökenli Oryantalist söylemlerin Osmanlı İmparatorluğu’nun ve Osmanlı devrindeki Filistin Yahudi cemaatinin tarihini çalışan İsrailli tarihçilerin eserlerine de sirayet ettiğini belirtir. ${ }^{81} \mathrm{Bu}$ açıdan bakıldığında, gaza tezinden gayrı-Müslimlere karşı Osmanlı hoşgörüsü klişesine, İstanbul'u alan "fanatik" Türklerin Akdeniz ticaretini kestiği iddiasından Osmanlı'nın son dört yüzyılına her alanda gerilemenin damgasını vurduğu kabulüne kadar ders kitaplarında gördüğümüz çeşitli söylemler de İsrail tarihyazımı tarafından Batı'dan devralınmış geleneksel Oryantalist söylemlerin bu kitaplardaki yansıması olarak görülebilir.

Ancak Oryantalizm dışında ikinci bir faktörün daha İsrail'de Osmanlı İmparatorluğu hakkında üretilen tarihsel söylemler ve dolayısıyla tarih ders kitapları

81 Maurus Reinkowski, "Late Ottoman Rule over Palestine: its Evaluation in Arab, Turkish and Israeli Histories, 1970-90," Middle Eastern Studies, 35, 1 (1999), s. 75-78. 
üzerinde etkili olduğu söylenebilir. Bu faktör de, akademik ve özellikle resmi tarih söyleminin hâlen içine oturduğu Siyonist çerçevedir. Reinkowski, Osmanlı dönemi Filistin Yahudi cemaatinin tarihini veya genel olarak Orta Doğu ve Osmanlı tarihini çalışan İsrailli tarihçiler konulara söz konusu çerçeveden bakmayı sürdürdükleri için, Filistin'in Siyonist göçlerden önce Osmanlı gerilemesinin olumsuz etkilerinden fazlasıyla nasibini almış, hatta bir dönem ileri sürüldüğü gibi “ç̈lleşmiş” bir bölge olduğunu vurgulamakta yarar gördüklerini belirtiyor. Filistin'deki Siyonist yerleşime ve onun Osmanlı yönetiminin getirdiği kısıtlamalara karşı sergilediği direnişe meşruiyet sağlanması için bir yandan Osmanlı rejiminin idari zayıflığı, ekonomik geriliği, acımasızlığı ve yozluğu vurgulanarak itibarsızlaştırılması, diğer yandan da bu olumsuzlukların bir devası olarak Siyonist göçün Batı etkisine ve modernleşmeye kapı açtığı tezinin işlenmesi gerekiyordu. Bir başka deyişle, modern Filistin tarihi için bir dönüm noktası olarak gösterilen Siyonist göçlerden önceki Osmanlı rejimi ne kadar olumsuz bir şekilde tasvir edilirse Filistin'deki Siyonist yerleşim dönemi de o kadar olumlu bir ışıkta görünecekti. ${ }^{82}$ Oryantalizmin etkilerinde olduğu gibi Siyonist söylemin İsrail tarihyazımındaki bu yansımalarını da ders kitaplarının incelediğimiz pasajlarında gözlemlemek mümkündür: İmparatorluğun ve özellikle Filistin’in geri kaldığı ve yolsuzluk, sömürü ve anarşiyle boğuştuğu klişelerinin yanısıra, Tanzimat reformlarının gayrı-Müslimlere eşitlik getirmekte ve gerçek bir modernleşme sağlamakta yetersiz kaldığı, Abdülhamit ve Jön Türklerin tabiiyetlerindeki halklara karşı baskıcı ve zalim politikalar izledikleri, Balkan halkları ve Ermenilere mezalim uygulandığı temalarının da kitaplarda gerek Filistin’e Siyonist göç ve yerleşimini gerekse de bölgenin daha sonra İmparatorluktan kopmasını meşrulaştırıcı bir işlev gördüğ̈̈ ileri sürülebilir.

Bunu izleyen çalışmalarda, İsrailli Arap öğrencilerin devam ettiği İsrail devlet okullarında kullanılan Arapça İsrail tarih ders kitaplarında Osmanlı İmparatorluğu tarihinin nasıl işlendiği konusunun araştırılması faydalı olacaktır. Bu bakımdan İbranice kitaplarla yapılacak bir karşılaştırma, daha bütünlüklü bir resme ulaşılmasına katkıda bulunacaktır.

82 Reinkowski, "Late Ottoman Rule over Palestine", s. 78-81. 
Öz — Bu çalışmada 1948'den 2014'e kadar İsrail'deki devlet okullarında kullanılmış olan İbranice tarih ders kitaplarında Osmanlı tarihinin nasıl işlendiği incelenmektedir. Tüm kitaplarda kuruluş dönemi ve fetihler anlatılırken gaza tezine dayanılmakta, Osmanlılar için gaza idealinin önemi vurgulanmaktadır. Klasik dönemindeki Osmanlı İmparatorluğu merkezi yönetimi, etkili ordusu ve gayrı-Müslimlere karşı hoşgörülü tutumuyla takdir edilmektedir. Buna karşılık eski yeni tüm kitaplar Osmanlı tarihyazımındaki gerileme paradigmasını kabul etmektedir ve 1990'larla sonrasında yayınlanan kitaplar gerileme devri olarak gördükleri döneme ağırlık verdikleri için sundukları Osmanlı imgesi daha olumsuzdur. Tüm kitaplarda İmparatorluğun 16. yüzyıldan sonra idaresi, ordusu ve ekonomisiyle zayıflayarak yolsuzluk ve anarşinin hüküm sürdüğü bir ülkeye dönüştügü anlatılmaktadır. Balkanlardaki isyanlar haklı bulunmakta ve yönetim isyancılara kıyım uygulamakla itham edilmektedir. Tanzimat dönemi reformlarının çoğunun muhafazakârların direnci yüzünden hayata geçirilemediği kaydedilmektedir. Abdülhamid idaresinin baskıcılığı vurgulanmakta, Jön Türklerin etnosentrik politikaları eleştirilmektedir. Çanakkale ve Filistin'deki savaşlar çoğunlukla İngiliz perspektifinden aktarılmaktadır. Ermeni olaylarının anlatımı eski kitaplarda yenilerine oranla Türkiye'nin resmi tarih tezlerine daha yakındır.

Anahtar kelimeler: İsrail, Osmanlı İmparatorluğu, tarih ders kitapları, gaza tezi, gerileme paradigmasi.

\section{Bibliyografya}

\section{Ders Kitaplarn}

Barnavi, Elie: Ha-Meah ha-20: Toldot 'Am Yisrael ba-Dorot ha-Aharonim [20. Yüzyıl: İsrail Halkının Günümüzdeki Tarihi], Tel Aviv: Sifre, 1998.

Bar-Hillel, Moshe, Shula Inbar: 'Olam Leumi [Milli Dünya], Bölüm 1, Petach Tikva: Lilach, 2008.

Domkeh, Eli'ezer (ed.): Ha-'Olam veha-Yehudim ba-Dorot ha-Aharonim [Günümüzde Dünya ve Yahudiler], Bölüm 2, Cilt 1, Kudüs: Zalman Shazar Center, 1999.

Domkeh, Eli'ezer, Hanah Urbach, Tsafrir Goldberg: Ha-Leumiyut: Reshit ha-Derekh [Milliyetçilik: Yolun Başı], Kudüs: Zalman Shazar Center, 2008.

Doron, Akiva (ed.): Mi-Dor le-Dor [Nesilden Nesile], Bölüm 3, Kudüs: Misrad ha-hinukh veha-tarbut, 1998.

Inbar, Shulah: Mahapekhah u-Geulah be-Yisrael uv-Amim [İsrail ve (Diğer) Halklar Arasında Devrim ve Özgürleşme], Bölüm 1, Petach Tikva: Lilach, 2006.

Katz, Jacob, Mosche Hershko: Yisrael veha-'Amim [İsrail ve (Diğer) Halklar], Bölüm 2, Tel-Aviv: Tel Aviv Dvir, 1974.

Kedem, Menahem: Perekim be-Toldot Yisrael ba-Mèot ha-18 veha-19 [18. ve 19. Yüzy1llarda İsrail (Halkı) Tarihinden Fasıllar], Tel Aviv: Or-'am, 1986. 
Kovarsky, Yuval: Ha-Leumiyut be-Yisrael uv-Amim: Reshit ha-Derekh 'ad 1920 [İsrail ve (Diğer) Halklar Arasında Milliyetçilik: Yolun başı, 1920’ye Kadar], Kinneret: Motsiim le-Or, 2014. Mish'ol, Yigal: Ha-Leumiyut ha-Modernit ve-Reshit ha-Tsiyonut [Modern Milliyetçilik ve Siyonizmin Başlangıc1], Me'ala Edomim: Hay Sikhol, 2011.

Na'aman, Shlomo, Aryeh Kasher: Toldot Yemey ha-Beynayim ba-'Amim uve-Yisrael [İsrail ve (Diğer) Halklar Arasında Ortaçă̆ Tarihi], Tel Aviv: 'Amihai 1972.

Naveh, Eyal: ha-Meah ha-20: Meah she-Hafka Sidrey 'Olam [20. Yüzyıl: Dünyanın Düzenini Değiştiren Yüzyıl], Tel Aviv: Sifre, 1995.

Orli, Iloni, Shalhevet Ofir, Zehavit Schenkolewski: Ve-Ele Toldot [İşte Tarih], Ramat Aviv: Matach, 2014.

Shavit, Shelomoh (ed.): Toldot Yisrael veha-Amim [İsrail ve (Diğer) Halkların Tarihi], Bölüm 2, Kudüs: Maalot, 1987.

Tabibiyan, Ketsi'ah (ed.): Masa' el ha-'Avar: Mi-Yemey ha-Beynayim ve-'ad ha-'Et ha-Hadasha [Geçmişe Yolculuk: Ortaçağdan Yakınçağa], Ramat Aviv: Matach, 1997.

Tcherikover, Victor: Historya Klalit [Genel Tarih], Cilt 5, Tel Aviv: Ts'erikover, 1970.

Toury, Jacob, Dan Helmut Schmidt: Toldot ha-Amim ba-Zeman ha-Hadash [Yakınçağda Halkların Tarihi], Cilt 3, Tel Aviv: Yavneh, 1967.

Toury, Jacob, Dan Helmut Schmidt: Toldot ha-Amim ba-Zeman ha-Hadash [Yakınçağda Halkların Tarihi], Cilt 2, Tel Aviv: Yavneh, 1973.

Zingrov, Israel, Shahar David: 'Am ve-'Olam [Halk ve Dünya], Cilt 1, Rehovot: 'Idan, 1998.

Ziv, Michael, Haim Hillel Ben-Sason, Jacob M. Landau: Divrey ha-Yamim [Kronikler], Cilt 2, Haifa: Yuval, 1959.

Ziv, Michael, Samuel Ettinger, Jacob M. Landau: Divrey ha-Yamim [Kronikler], Cilt 4, Bölüm 1, Haifa: Yuval, 1963.

Ziv, Michael, Jacob Toury: Divrey ha-Yamim - ha-Zeman ha-Hadash [Kronikler - Yakınçağ], Cilt 2, Tel Aviv: Yavneh, 1958.

Ziv, Michael, Jacob Toury: Divrey ha-Yamim - ha-Zeman ha-Hadash [Kronikler - Yakınçă̆], Cilt 1, Tel Aviv: Yavneh, 1973.

\section{Araştırma Eserleri}

Abu-Saad, Ismael: "The Portrayal of Arabs in Textbooks in the Jewish School System in Israel," Arab Studies Quarterly, 29/1 (2007), s. 21-38.

Alibatić, Ahmet: "Images of the Ottomans in History Textbooks in Bosnia and Herzegovina," İslâm Araştırmaları Dergisi, 17 (2007), s. 103-37.

Alpargu, Mehmet: “Türkiye ve Azerbaycan Tarih Ders Kitapları Üzerine Bazı Gözlemler," Atatürk Dergisi, 5 (2007), s. 1-13.

“Balkan ve Karadeniz Ülkelerinde Güncel Tarih Ders Kitaplarında Osmanlı/Türk İmajı,” TÜBİTAK 1001 Projesi, Proje No. 110K571, Proje Yürütücüsü Mehmet Hacısalihoğlu, İstanbul, 2014. 
Balta, Evren, Süheyla Demir: "Tarih, Kimlik ve Dış Politika: Rusya Federasyonu Güncel Tarih Ders Kitaplarında Osmanlı-Türk İmajı,” Bilig, 76 (2016), s. 1-31.

Bar-Gal, Yoram: “The Image of the 'Palestinian' in Geography Textbooks in Israel," Journal of Geography, 93/5 (1994), s. 224-32.

Bar-Tal, Daniel: "The Arab Image in Hebrew School Textbooks," Palestine-Israel Journal, 8/2 (2001), s. 5-18.

Bilmez, Bülent: “Arnavutluk Tarih Ders Kitaplarında Osmanlı/Türk İmgesi,” Osmanlı Araştırmaları, 49 (2017), s. 343-80.

Braude, Benjamin, Bernard Lewis: "Introduction," B. Braude ve B. Lewis (ed.), Christians and Jews in the Ottoman Empire: The Functioning of a Plural Society, vol. 1: The Central Lands, New York: Holmes and Meier Publishers, 1982, s. 1-34.

Çelik, Hülya, M. Bilal Çelik: "Devrim Sonrası İran Ortaokul Tarih Ders Kitaplarında Türklere İlişkin Söylemlerin Analizi,” Türk Tarih Eğitimi Dergisi, 4 (2015), s. 202-24.

Deveci Bozkuş, Yıldız: “Ermeni Tarih Ders Kitaplarında Türk İmgesi," Yeni Türkiye, 60 (2014), s. $1-45$.

Deveci Bozkuş, Yıldız: "Ermeni Tarih Ders Kitaplarında 1915 Olayları," TESAM Akademi Dergisi, 2 (2015), s. 89-105.

Deveci Bozkuş, Yıldız: Ermeni Ders Kitaplarında “Türkler”, Ankara: TEPAV, 2016.

Emecen, Feridun M.: Yavuz Sultan Selim. İstanbul: Kapı Yayınları, 2016.

Erdönmez, Celâl: "Kıbrıs Tarihi Ders Kitaplarında Osmanlı Devrinde Kıbrıs’a Yapılan Sürgünlerle İlgili Bazı Tespitler," SDÜ Fen Edebiyat Fakültesi Sosyal Bilimler Dergisi, 15 (2007), s. 65-90.

Erözden, Ozan: "Hırvatistan Tarih Ders Kitaplarında Osmanl1-Türk İmajı"” İ. Ü. Siyasal Bilgiler Fakültesi Dergisi, 50 (2014), s. 39-54.

Ersoy Hacısalihoğlu, Neriman: "Bulgaristan Tarih Algısında ve Tarih Ders Kitaplarında Devşirme Sistemi ve Yeniçeriler," Tarih Dergisi, 66 (2017), s. 129-54.

Greene, Molly: "Resurgent Islam: 1500-1700," David Abulafia (ed.), The Mediterranean in History, London: Thames \& Hudson, 2003, s. 219-50.

Hacısalihoğlu, Mehmet: "II. Meşrutiyetin Balkan Ülkelerinde Algılanması ve Jön Türk İmajı," 100. Yılında II. Meşrutiyet; Gelenek ve Değişim Ekseninde Türk Modernleşmesi Uluslararası Sempozyumu, ed. Zekeriya Kurşun, Cemil Öztürk, Yasemin Tümer Erdem, Arzu M. Nurdoğan, Istanbul: Marmara Üniversitesi Yayınları, 2009, s. 549-56.

Hathaway, Jane: "Problems of Periodization in Ottoman History: The Fifteenth through the Eighteenth Centuries," The Turkish Studies Association Bulletin, 20 (1996), s. 25-31.

Howard, Douglas: "Ottoman Historiography and the Literature of 'Decline' of the Sixteenth and Seventeenth Century," Journal of Asian History, 22 (1988), s. 52-77.

İnalcık, Halil: "Istanbul," Encyclopedia of Islam, $2^{\text {nd }}$ Edition, IV (Leiden: Brill, 1997), s. 224-48. İsov, Mümin: "Bulgaristan Tarih Ders Kitaplarında Türk Azınlığın Yerine İlişkin Bazı Gözlemler," Balkan Araştırma Enstitüsü Dergisi, 3 (2014), s. 37-51.

Kafadar, Cemal: "The Question of Ottoman Decline," Harvard Middle Eastern and Islamic Review, 4/1-2 (1997-98), s. 30-75. 
Kapar, Mehmet Ali: "Sovyetler Birliği Dönemi Ders Kitaplarında Eskiçă̆ Tarihi ve Eski Türk Tarihi’nin Öğretimi,” USAD, 5 (2016), s. 239-52.

Kechriotis, Vangelis: "History as a Public Claim and the Role of the Historian: Two Recent Debates Regarding the Ottoman Past in Greece and Bulgaria," E. Ginio ve K. Kaser (ed.), Ottoman Legacies in the Contemporary Mediterranean, the Balkans and the Middle East Compared, Jerusalem: The European Forum at the Hebrew University, 2013, s. 287-310.

Kınıklığlu, Suat: "Images and Representations of Turks and Turkey in Soviet History Textbooks," International Textbook Research, 29 (2007), s. 259-71.

Kuran-Burçoğlu, Nedret: "A Glimpse at Various Stages of the Evolution of the Image of the Turk in Europe: $15^{\text {th }}$ to $21^{\text {st }}$ Centuries," Mustafa Soykut (ed.), Historical Image of the Turk in Europe: $15^{\text {th }}$ Century to the Present, İstanbul: The Isis Press, 2003, s. 21-42.

Kutlu, Sacit: "Bulgar Kolektif Bellek İnşasında bir 'Hatırlama ve Unutma Yeri'," Toplumasal Tarih, 181 (Ocak 2009), s. 33-39.

Lewis, Bernard: The Jews of Islam, Princeton: Princeton University Press, 1984.

Lowry, Heath W.: The Nature of the Early Ottoman State, Albany: State University of New York Press, 2003.

Mallet, Laurent-Olivier: La Turquie, Les Turcs et les Juifs : histoire, représentations, discours et strategies, Istanbul: Les Editions Isis, 2008.

Muhasilović, Jahja: "Image of the Ottomans in Bosnian Textbooks Published After 2007," Epiphany - Journal of Transdisciplinary Studies, 7/2 (2014), s. 82-91.

Naveh, Eyal: "La imagen de Europa y del mundo árabe-islámico en el currīculo escolar y los libros de texto de historia en Israel," Luigi Cajani (ed.), Conociendo al otro: El islam y Europa en sus manuales de historia, Madrid: Fundación ATMAN, 2008, s. 173-214.

Nets-Zehngut, Rafi. "Israeli Approved Textbooks and the 1948 Palestinian Exodus," Israel Studies, 18/3 (2013), s. 41-68.

Owen, Roger: "The Middle East in the Eighteenth Century - An 'Islamic' Society in Decline? A Critique of Gibb and Bowen's Islamic Society and the West," Bulletin (British Society for Middle Eastern Studies), 3/2 (1976), s. 110-17.

Peled-Elhanan, Nurit: Palestine in Israeli School Books: Ideology and Propaganda in Education, London: I.B. Tauris, 2012.

Pingel, Falk: The European Home: Representations of 20 $0^{\text {th }}$ Century Europe in History Textbooks, Strasbourg: Council of Europe, 2000.

Pingel, Falk: UNESCO Guidebook on Textbook Research and Textbook Revision, $2^{\text {nd }}$ Edition, Paris and Braunschweig: UNESCO and Georg Eckert Institute, 2010.

Podeh, Elie: "History and Memory in the Israeli Educational System: The Portrayal of the Arab-Israeli Conflict in History Textbooks (1948-2000)," History \& Memory, 12/1 (2000), s. 65-100.

Pirický, Gabriel: "The Ottoman Age in Southern Central Europe as Represented in Secondary School History Textbooks in the Czech Republic, Hungary, Poland and Slovakia," Journal of Educational Media, Memory, and Society, 5 (2013), s. 108-29. 
Podeh, Elie: The Arab-Israeli Conflict in Israeli History Textbooks, 1948-2000, Westport, CT: Bergin \& Garvey, 2002.

Podeh, Elie: "Univocality within Multivocality: The Israeli-Arab-Palestinian Conflict as Reflected in Israeli History Textbooks, 2000-2010," Journal of Educational Media, Memory, and Society, 2/2 (2010), s. 46-62.

Popek, Krzysztof: "The Manipulation of Photographs by Dimitar Cavra and its Influence on the Creation of the Myth of the Batak Massacre (1876) in Bulgarian Historiography," Alicja Bemben, Rafał Borysławski, Justyna Jajszczok ve Jakub Gajda (ed.), Cryptohistories, Newcastle upon Tyne: Cambridge Scholars Publishing, 2015, s. 115-26.

Reinkowski, Maurus: "Late Ottoman Rule over Palestine: its Evaluation in Arab, Turkish and Israeli Histories, 1970-90," Middle Eastern Studies, 35/1 (1999), s. 66-97.

Shaw, Stanford J., Ezel Kural Shaw: History of the Ottoman Empire and Modern Turkey, vol. 2: Reform, Revolution, and Republic: The Rise of Modern Turkey, 1808-1975, Cambridge: Cambridge University Press, 1977.

Stradling, Robert: Teaching 20 th Century European History, Strasbourg: Council of Europe, 2001.

Şimşek, Ahmet, Nigar Maharramova Cengiz: "Rusya Tarih Ders Kitaplarında Türk-Osmanlı İmgesi,” Türk Tarih Ĕ̈itimi Dergisi, 4 (2015), s. 225-58.

Tak, İsa, Nurses Yıldız: “1980-1990 Yılları Arasında Bulgaristan’da İlköğretim ve Ortaöğretim Kurumlarında Okutulan Tarih Ders Kitaplarında Türk ve Osmanlı Algısı,” Uluslararası Türk Ë̆itim Bilimleri Dergisi, 2 (2014), s. 67-100.

Tezcan, Selim, Mehmet Sadık Gür, Alper Sarıbaş: "İsrail Tarih Ders Kitaplarında Türk İstiklal Savaşı ve Cumhuriyet Dönemi,” Bilig, 86 (2018), s. 137-67.

Tezcan, Selim, Mehmet Sadık Gür, Alper Sarıbaş: “İsrail Tarih Ders Kitaplarının (19482014) Gözünden Selçuklular: Filistin-Kudüs Hâkimiyetleri ve Haçlı Seferleri ile Cihad Hareketinin Başlangıcındaki Rolleri,” Filistin Araştırmaları Dergisi, 2 (2017), s. 103-33.

Tezcan, Selim, Alper Sarıbaş, Mehmet Sadık Gür: “İsrail Tarih Ders Kitaplarının (1948-2014) Gözünden Tanzimat’a Kadar Osmanlı-Yahudi İlişkileri,” TYB Akademi, 7, 21 (2017), s. 77-103.

Thomas, David, John Chesworth (ed.): Christian-Muslim Relations: a Bibliographical History, vol. 8: Northern and Eastern Europe (1600-1700), Boston: Brill, 2016.

Ural, Selçuk: "Makedonyada 6, 7 ve 8. Sınıf Türkçe Tarih Ders Kitaplarında Osmanlı-Türk Alg1sı," Tarih Okulu Dergisi, 7 (2014), s. 797-826.

Wittek, Paul: The Rise of the Ottoman Empire: Studies in the History of Turkey, Thirteenth-Fifteenth Centuries, ed. Colin Heywood, New York: Routledge, 2012. 